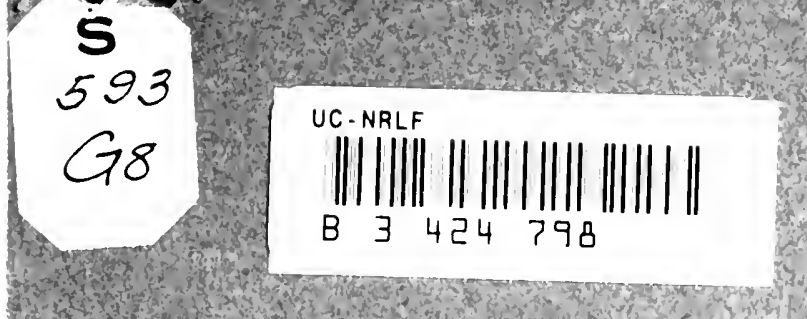




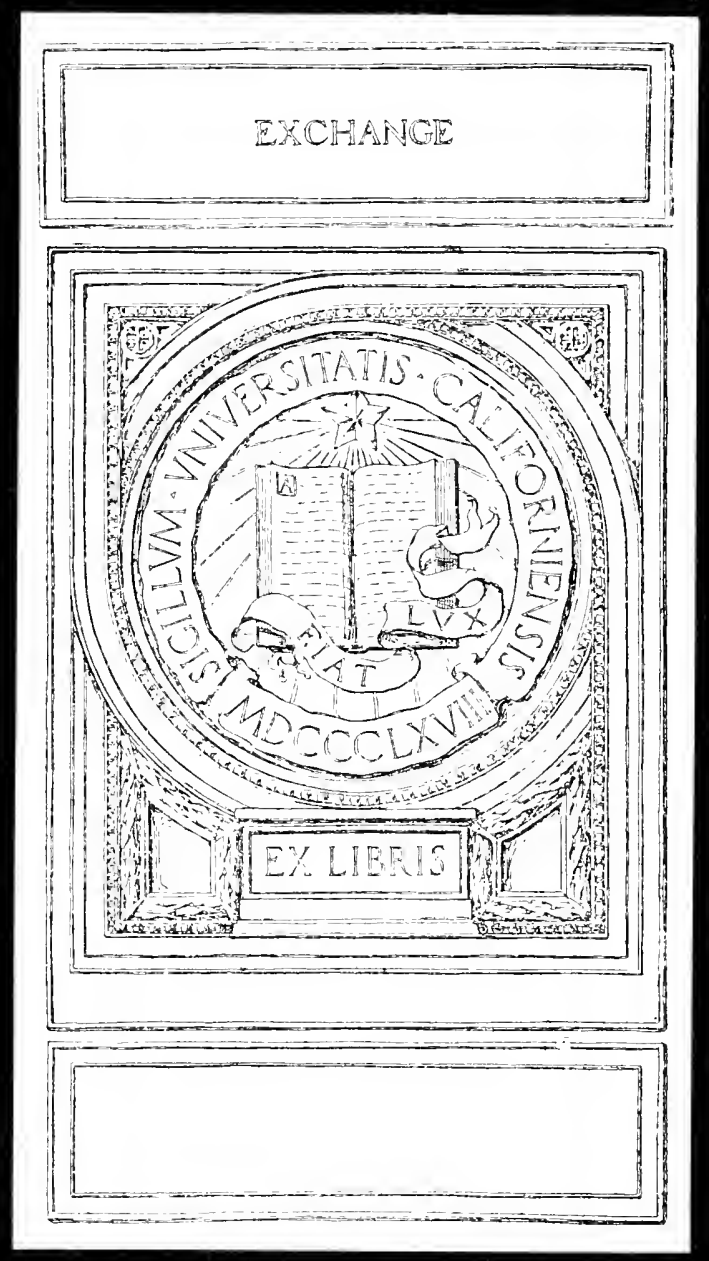

8061 'IL AUS I IVd a N 'asnoeiks siayer soIg pIoIkes sәрu!g 


\section{THE EFFECT OF DRYING SOILS ON THE WATER-SOLUBLE CONSTITUENTS}

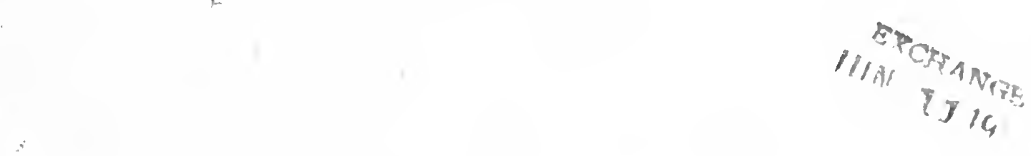

\section{A THESIS}

PRESENTED TO THE FACULTY OF THE GRADUATE SCHOOL OF CORNELL UNIVERSITY FOR THE DEGREE OF DOCTOR OF PHILOSOPHY

BY

A. F. GUSTAFSON, M.S.

SEPTEMBER, 1920

Reprinted from Soll Sclence, Vol. 13. No. 3, March, 1922. 


\title{
THE EFFECT OF DRYING SOILS ON THE WATER-SOLUBLE CONSTITUENTS
}

\author{
A THESIS \\ PRESENTED TO THE FACULTY OF THE GRADUATE SCHOOL \\ OF CORNELL UNIVERSITY FOR THE DEGREE OF \\ DOCTOR OF PHILOSOPHY
}

BY

A. F. GUSTAFSON, M.S.

SEPTEMBER, 1920 


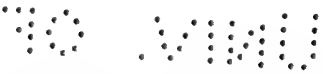

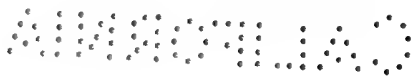




\title{
THE EFFECT OF DRYING SOILS ON THE WATER-SOLUBL.E CONSTITUENTS ${ }^{1}$
}

\author{
A. F. GUSTAFSON \\ New Iork State College of Agriculture at Cornell University
}

Received for publication, May 1, 1921

\section{INTRODUCTION}

The effect of drying and of burning soil on the growth of crops was noted in the field by the Roman farmer many years before the beginning of the science of soils. At first, improvement in the crop was attributed to the well known effect of drying on the physical condition of medium and fine-grained soils; later, as chemistry developed, the increased growth was considered to be due to some chemical change which occurred in the soil during the process of drying; while a more recent idea is that the improvement is brought about by readjustment in the microscopic life of the soil.

For several decades greenhouse growers have practiced heating the soil to kill various plant and animal enemies of the crop. In many instances the improvement in growth was greater than could have been affected by sterilization alone, the rank growth of stem and dark green color of leaf being particularly noticeable. Some growers have found it necessary to withhold a portion of the nitrogen usually supplied, to avoid excessive growth of the vegetative portion of the plant and thus permit proper fruiting.

It is the purpose of this paper to review the observed effects of drying and lieating soils, and to present some experimental data indicating the effect of drying, and of heating at $105^{\circ} \mathrm{C}$., on the amount of total water-soluble solids recovered by extraction with distilled water.

\section{Davy (17) says:}

\section{REVIEW OF LITERATURE}

"The improvement of lands by burning was known to the Romans. It is mentioned by Virgil in the first book of the Georgics. It is a practice still much in use in many parts of these islands; the theory of its operation has occasioned much discussion, both amongst scientific men and farmers. It rests entirely upon chemical doctrines; and I trust I shall be able to offer you satisfactory elucidations on the subject."

Also:

"When clay or tenacious soils are burnt, . . . . they are brought nearer to a state analogous to that of sands. . . . . All poor siliceous sands must be injured by it (burning), and here practice is found to accord with the theory."

${ }^{1}$ A thesis submitted to the Faculty of the Graduate School of Cornell University in partial fulfillment of the requirements for the Degree of Doctor of Philosophy, September, 1920. 
$\therefore: \therefore: \because \because \cdots: \quad \therefore \quad \cdots$

Warington (for) working ritls snils thit diat been dried at $55^{\circ} \mathrm{C}$. for 8 hours found that the first $150 \mathrm{cc}$. of extract from 7 pounds of dry powdered soil, contained all the chlorides and 98.8 per cent of the nitrates. He states that, if the soil were wet, a much greater volume of water would be required to leach out all the chlorides and nitrates as it would be necessary to displace all the water present in the soil. lle noted that oven-drying caused a reduction in quantity of nitrates, that the decrease was not so great when the soil was dried slowly and that, when air-dried at $10^{\circ} \mathrm{C}$., there was an increase in nitrates.

Frank (24) extracted $30 \mathrm{gm}$. of soil with 2 liters of distilled water, comparing unheated, air-dry soil with the same heated in an autoclave at $100^{\circ} \mathrm{C}$. Heating increased the total soluble matter in sand 50 per cent and in the swamp soil over 150 per cent. The soluble organic matter was almost trebled in each case. Larger crops of oats and yellow lupines were produced on the heated soils.

Liebscher $(60)$ found that lieating soil with steam increased the solubility of phosphorus and nitrogen compounds.

Schmoeger (88) heated moor soil at 150 to $160^{\circ} \mathrm{C}$. for 10 hours, with the result that the phosphorus soluble in hydrochloric acid was doubled.

Deherain and Demoussy (18) heated two soils in an autoclave at $120^{\circ} \mathrm{C}$. for 1 hour. When these heated soils were inoculated with fresh soil, they produced more nitrate nitrogen and ammonia than did the original soils.

Pfeiffer and Franke (73) heated soil under a pressure of 1 atmosphere for 3 hours. The soil so treated produced a larger crop of mustard than the unheated soil and it contained a higher percentage of nitrogen.

On heating a garden soil in an oven at $100^{\circ} \mathrm{C}$., on 3 successive days, Richter (82) found that the amount of water-soluble organic matter trebled, and the total soluble matter almost doubled.

Tacke (100) showed that a fresh swamp soil contained very little water-soluble phosphorus, and drying at 70 to $80^{\circ} \mathrm{C}$. rendered more than half of the total phosphorus soluble in water.

Tacke and Immendorf (101) found the solubility of phosphorus and potassium in some swamp soils was increased by drying at $80^{\circ} \mathrm{C}$. In another experiment they found heating at 100 and $180^{\circ} \mathrm{C}$. doubled and trebled, respectively, the amount of water-soluble phosphorus.

Stone and Smith (99) report that heating soil improves the color and causes an acceleration of growth of lettuce, cucumbers and tomatoes and that saprophitic fungi not found in unheated soil grew profusely on heated soil, indicating a change in the organic matter.

Kriger and Schneidewind (58) showed definitely that soluble nitrogen and phosphorus was greatly increased by heating. On both unmanured soil and that supplied with sodium nitrate, the growth of mustard was nearly doubled by heating the soil before planting.

Deitrich (19) heated garden soil and secured increased crops; but, curiously enough, pasture soils did not respond in the same way.

Whitney and Cameron (103) found that air-dried soils, in general, had more soluble phosphoric acid, nitric acid, calcium and potassium than fresh soils, and that with few exceptions oven-dried soils had still greater quantities of these materials in soluble form. Nitric acid was most variable.

Card and Blake (9) report in each of two trials, a decrease in yield of lettuce due to soil sterilization, while in one trial radishes gave an increase where nitrate of soda was added to sterilized soil.

Hassenbaümer, Coppenrath, and König (29) report that the solubility of inorganic constituents was increased when $250 \mathrm{gm}$. of soil and 3 liters of water were heated together under a pressure of 3 atmospheres for 3 hours.

King (45) reviewed fully the recorded experimental work on water extracts of soils and extraction with dilutc acids. These reports date back to the work of Grouven in 1858 and include that of Wunder and Eiclihorn, 1860, Peters, 1860, Jarriges, 1861-1862, Hoffman, 1863, Schulze, 1864, and Iayden, 1865. Nearly all of these investigators report potash, 
lime, magnesia, soda, oxide of iron and aluminum, phosphoric, sulfuric and carbonic acids, chlorine, silica and organic matter separately. Their results vary greatly for any one constituent because of the wide range of soils, temperatures and moisture contents used.

These results are especially interesting since several of them were obtained by methods essentially similar to those of King, who used $100 \mathrm{gm}$. of soil and $500 \mathrm{cc}$. of distilled water. The soil was stirred in a mortar with enough water to make a thick paste in order to break down all granules, after which the remainder of the $500 \mathrm{cc}$. of water was added. Then the supernatant, turbid liquid was transferred to a pint Mason jar and, usually within 15 minutes, to the Pasteur-Chamberland filter chamber.

Filtration was accomplished by a pressure of 30 to 40 pounds. Clear extracts were obtained in 5 to 20 minutes, depending on the type of soil, and the amount of clay and fine silt remaining in suspension to coat the walls of the filters. It was during the 3 minutes of active agitation that the main part of actual solution occurred. It was found that longer washing did not materially increase the amount of salts going into solution. At first the electrical-resistance method was employed for determining concentration but it was found more accurate to evaporate definite quantities of the extract, dry in an oven and weigh. $\mathrm{NO}_{3}, \mathrm{HPO}_{4}, \mathrm{Cl}$ and $\mathrm{SiO}_{3}$ were determined by methods described by Whitney and Cameron (103). Comparisons were made of the salts that could be recovered from fresh soil, soil quickly sun-dried and from that oven-dried at $110^{\circ} \mathrm{C}$. Eight soils in four 1-foot sections were used. In the surface foot, of four soils the oven-dry soil had more nitrates, while in the other four, the fresh, moist soil had more; but in the second, third, and fourth sections the nitrates were increased 108, 134 and 61 per cent, respectively. In two of the eight soils the fresh sample showed considerably more $\mathrm{HPO}_{4}$ in the first section than the dry and in eight instances in the other 3 feet out of the 24 possible cases the fresh soil was slightly higher. In every case (except one in fourth foot), the dry soil gave up much more $\mathrm{SO}_{4}$; for the eight soils the average increase for the four sections was $265,310,281$ and 79 per cent, respectively. In one instance only was the fresh soil significantly higher in $\mathrm{HCO}_{3}$ while in the others the dry was from 48 to 73 per cent higher. Silica was 588, 322, 237 and 236 per cent higher in the oven-dried soil in the four sections. Chlorine was the only element that, on the average, was recovered in smaller quantity from the dry soil. The other acid radicals ran from 1.26 times as much nitrates up to 6.58 times as much of silica in the dry as in the fresh soil.

Later, determinations were made of potash, lime and magnesia in the extract of fresh and oven-dried soils. In part II, King reports good correlation between quantity of soluble salts found, especially $\mathrm{HPO}_{4}$, and crop yields for the different soil types under investigation.

King concluded that in oven-drying the last of the moisture, for a time at a temperature near the boiling point, increases the solubility of salts and might be expected also to render the organic matter more soluble. He also concluded that when a soil dries its salts are deposited as crystals on the soil particles and salts within the granules are left on the exterior. As the soil is stirred in water, these salts go into solution readily. On the other hand, in a moist soil the solution is simply diluted by adding water and the dissolved salts are disseminated through it in part by diffusion, a slow process. The solution from the dry soil is removed from it before readsorption occurs. Thus, he explains the recovery of more soluble material from the dry than the moist soil.

Hilgard (30) considered the unusual productiveness of desert soils when properly watered, due to an abundant supply of plant nutrients rendered available by the intense heating to which these soils are subjected during the warm season. With King he believed that the soluble salts, on drying, are deposited on the surface of the particles whence they may be "readily abstracted by the first touch of the solvent water," and that soils retain salts in a condition of purely physical adsorption.

Stone and Monohan (98) noted that sterilizing loam increased the growth of soybeans 14 per cent, but that sterilizing in the same way decreased the growth of soybeans in subsoil 57.7 per cent. The subsoil pots showed poor, sickly development. 
Schulze (91) noticed injurious effects from sterilization at 100 to $125^{\circ} \mathrm{C}$. for 1 hour, in the early stages of growth, but later these plants became more vigorous and produced a larger crop, except peas and mustard on one soil.

Darbishire and Russell (16) heated soil at 90 to $95^{\circ} \mathrm{C}$. and obtained very marked increases; the wheat yield (grain), from heated soil was 3.5 times as great as from unheated, and spinach, tomato and verbena, gave over four times the yield on the heated soil. The second crop, and even the third in one case, showed the same influence, though there was no increase in legumes. Heating to higher temperatures somewhat intensified the effect.

Koch and Lüken (55) heated a poor sandy soil in an autoclave for 2 hours under pressure of two atmospheres. This almost doubled the total soluble solids, quadrupled the soluble organic matter, but increased the soluble inorganic material only slightly. Even though heated and unheated soils were fertilized alike, the heated one produced the larger crop of oats. Injurious effects following heating were noticeable, but with crops seeded later in the season this influence was not great.

Rahn (81) made an extensive study of the effect of drying on soils. After drying at room temperature, he secured markedly increased bacterial activity, the difference being greater in heavy, rich soils, and incrcased growth of mustard.

Pickering (74) heated a soil at $200^{\circ} \mathrm{C}$. for 2 hours, finding that 2 year-old apple trees made 63 per cent more growth, produced 48 per cent more leaves containing 52 per cent more dry matter than did similar trees in untreated soil. Heating in a moist condition increased the soluble matter, both organic and mineral, more than when heated in the dry condition. Heating soil at $100^{\circ} \mathrm{C}$. in a closed vessel (75) increased total soluble matter 25 per cent in one case and 107 per cent in another, and in 11 soils an average increase from 0.052 to 0.360 per cent of soluble organic matter and from 0.111 to 0.475 per cent of total soluble matter was secured.

Gedroitz (25) found that sterilization brought about an increase in the solubility and assimilability of nutritive substances.

Russell and Hutchinson (86) report that heating soil at $98^{\circ} \mathrm{C}$. increased the yield of rye 60 per cent and buckwheat 31 per cent.

Mann (64) gives a brief account of the "Rab" system of rice growing, viz., "burning a mass of branches of trees or cow dung on the land" where rice is to be seeded. He states that it is an almost universal practice on the trap and laterite soils of western India and is considered essential to rice culture there. The surface soil is heated sufficiently to change the bacterial flora, increase the soluble organic matter and improve the physical condition of the soil.

King (46) treated sand repeatedly with disulfonic acid to free it from all traces of nitric acid and organic matter, then charged it with potassium nitrate, which, after a time, was drained away. After the sand dried, $50 \mathrm{gm}$. were washed with $100 \mathrm{cc}$. of distilled water, the mass was stirred continuously for 3 minutes, the solution drained from the sand and the nitric acid determined. This was repeated until ten washings in all had been made. Table A gives the results of these determinations.

After the tenth washing the sand was treated with disulfonic acid, as is the residue in an ordinary nitrate determination, and was shown to contain $0.8 \mathrm{mgm}$. of nitrates, or nearly three times the amount recovered in the second washing, more than one-fourth as much as recovered in the first washing.

King reasoned from this that each sand grain "appropriated to itself" a film of water with potassium nitrate in solution and this film adhered to the particle so closely that in stirring after adding $100 \mathrm{cc}$. of distilled water the nitrate was given up by diffusion only and not by forming a mechanical mixture of the distilled water with the film.

Lyon and Bizzcll (61) found that steaming for 2 to 4 hours under 2 atmospheres pressure increased water-soluble ammonia, organic nitrogen, nitrites and total soluble matter, but lessened the amount of nitrates. On standing 56 to 90 days after heating, there was a decreasc in these soluble materials, except nitrates which remained constant. Wheat grown in 
steamed soils at first showed injury, but later recovered and grew better than plants on the unsterilized soil.

Two soils heated for 2 hours at 2 atmospheres pressure and another for 4 hours (62), were extracted with 5 parts of water to 1 part of soil. Total solids and inorganic matter were increased from two to six times by this heating. All other constituents except nitrates were greatly increased by heating. No ammonia was found in any unheated soil and the concentration of nitrates was decreased by heating in every case. Wheat produccl a much larger crop on the heated than on the unheated soil, and the same effect was very evident in the succeeding crop of millet, but wheat seedlings grown in a 1.1 extract marle immediately after steaming, were affected unfavorably. Diluting the extract of steamed soil with distilled water, 3 to 1 , improved the growth of seedlings but diluting the extract of untreated soil decreased the growth of seedlings.

The same writers (62) report that soils whose moisture content was maintained at about 25 per cent by adding distilled water, for periods of 56,82 and 90 days after heating, steadily lost in total water-soluble material so that at the end of 90 days there was but slightly more

TABLE $\mathrm{A}^{2}$

Observed and computed concentration of nilrate in successive washings of sand in distilled water

\begin{tabular}{|c|c|c|c|}
\hline \multirow{2}{*}{ NUMBER OF WASHING } & \multirow{2}{*}{ WATER RETAINED IN SAND } & \multicolumn{2}{|c|}{ CONCENTRATION OF SOLUTION } \\
\hline & & Observed & Computed \\
\hline & $g m$. & $p \cdot p \cdot m$ & $p \cdot p \cdot m$. \\
\hline 1 & 12.7 & 35.750 & 43.4551000 \\
\hline 2 & 13.2 & 3.300 & 4.8969000 \\
\hline 3 & 13.1 & 0.451 & 0.5710100 \\
\hline 4 & 13.4 & 0.174 & 0.0661390 \\
\hline 5 & 13.05 & 0.138 & 0.0078153 \\
\hline 6 & 13.3 & 0.128 & 0.0009023 \\
\hline 7 & 13.5 & 0.110 & 0.0001059 \\
\hline 8 & 13.5 & 0.110 & 0.0000126 \\
\hline 9 & 13.5 & 0.110 & 0.0000015 \\
\hline 10 & 13.4 & 0.110 & 0.0000002 \\
\hline
\end{tabular}

than one-fourth as much soluble material present as immediately after heating. Nitratcs decreased also, but in one soil they seemed to recover in part at the close of the period.

In a more extended experiment along the same line, soils stood 34 and 39 days after heating. Total solids, inorganic matter and ammonia nitrogen decreased rapidly, while there was a slight increase in nitrates in the same time.

Fletcher (23) relates that burning organic matter, twigs or manure, or both, greatly increased the yield of crops, but not to so great an extent as did heating the soil directly at 200 to $230^{\circ} \mathrm{F}$.

Aitken (1) reports an instance of increased productiveness following heating of the surface garden soil by a "large and long-continued fire."

Howard and Howard (36) mention the beneficial effects, noted in parts of India, of exposing soil to the strong heat and light of the sun in April and May.

In soils kept moist for various lengths of time in open pans, Pickering (76) noted that the soluble matter, both organic and inorganic, increased as the temperature was raised from 30 to $150^{\circ} \mathrm{C}$. The quantity of soluble matter decreased as the time since heating increased, up to 112 days when the last determination was made. In case of the inorganic matter at

${ }^{2}$ Letters used for tables derived from the literature. 
$100^{\circ} \mathrm{C}$., however, there was an increase at both 44 and 112 days. When the soils were kept in sealed flasks there was an increase after 10 days in every case except that of inorganic matter at $125^{\circ} \mathrm{C}$. When stored in sealed flasks for 43 days, the soils heated at 100 and $125^{\circ} \mathrm{C}$. showed slight increase of soluble matter. When stored for 116 days there was a gain in the amount of soluble organic matter at the above temperatures but a loss in the quantity of soluble inorganic matter. Storing in light or darkness made no appreciable difference. In the case of the soil that had been heated at $125^{\circ}$ there was no difference in organic matter whether stored at $15^{\circ}$ or $5^{\circ}$, but that was a rather marked increase of inorganic matter for the lower temperature.

Pickering (77) secured increased growth of grasses and non-grasses (except in a preliminary experiment with the latter) when planted in soils previously heated. The amount of growth increased as higher temperatures were used. This increased growth correlates fairly closely with increase in soluble material, both organic and inorganic, resulting from heating.

Hall (26) says, in speaking of effect of sterilization of soil, "Approximately, the crop becomes doubled if the soil has been first heated to a temperature of 70 to $100^{\circ} \mathrm{C}$. for 2 hours," while volatile antiseptics bring "about an increase of 30 per cent or more."

Russell (85) discusses briefly the beneficial effects of sterilization by heat and antiseptics, and assigns killing of the larger soil organisms which destroy the beneficial ones, as the explanation of the effect of this treatment.

Dyer (20) states that commercial vegetable growers near London partially sterilize their greenhouse soils with steam and if they use the ordinary amount of nitrogenous fertilizer the plants grow so rank as to "spoil their bearing capacity."

Seaver and Clark (92) heated soils from New York, Massachusetts and North Dakota. They found that the soluble matter in extracts of heated soils was generally six to ten times as great as that from the same soil not heated. The increase varied somewhat with the organic content of the soil, the temperature to which it was heated, and the period of heating.

Hinson and Jenkins (31) state that tobacco plants in steamed soils start quicker and grow faster than in unheated soil. They think this accelerated growth due to warming the soil, possible solvent action of the steam on the plant-food, but surely, in part, to change in the "microbe life in the soil."

In Kentucky, it is a common practice among tobacco growers to heat or burn the soil of the tobacco beds to kill weed seeds and disease.

Nagoaka (69) reports a material increase in solubility of phosphorus in dilute acids after heating the soil. IIc found autoclave heating had greater effect on solubility than other methods.

Peterson (72) heated wavellite and found that it increased the quantity of phosphorus soluble in $0.2 \mathrm{~N}$ nitric acid from 4.12 per cent of the total phosphorus, in unheated material, to 54.9 per cent in wavellite heated to $160^{\circ} \mathrm{C}$., 49.0 per cent at $200^{\circ}$, and 98.7 per cent at $240^{\circ} \mathrm{C}$. He noted little effect on soil at $100^{\circ} \mathrm{C}$. but at $200^{\circ}$, after a five-hour treatment, there was a marked increase in solubility of phosphorus.

Ritter (83) experimented along the same lines as Rahn and found that drying increased bacterial activity, and with less effect on light than on heavy soils.

liischer (22) comments on the work of Rahn and Ritter, but holds the chemical factor more important than the bacterial. He attaches much importance to oxidation since drying increases the amount of nitrates, even though it kills nitrifying organisms; also credits colloids and surface tension with playing important rôles.

Schreiner and Lathrop (90) in studying the chemistry of steam-heated soils made 1 to 4 extracts. Many organic compounds were found in heated soil that were not isolated from fresh soil. Dihydroxystearic acid was increased when present in the fresh soil and produced when not present. Seedlings were grown in the extracts for 10- and 15-day periods; extracts from heated soil depressed growths. Heating increased acidity.

Skalskii (94) found that sterilizing with chloroform and with heat increased the yield of crops by converting phosphoric acid and nitrogen into available forms. 
Stone and associates (97) report greatly increased bacterial devclopment in cxtracts from soils rich in organic matter, which had been heated previously, while it was retarded in extracts from poor soils. They consider the chemical factor most important in accounting for the effect of heating.

Leather (59) in studying the nitrate content of soils, at Pusa states that drying in the sun effected an increase as great as 400 per cent.

Seaver and Clark (93) found an increase in total soluble solids, organic matter, inorganic matter and total nitrogen, in soil when heated at $90^{\circ} \mathrm{C}$. and still greater increases at 120 , 150 and $170^{\circ} \mathrm{C}$. Plant growth was accelerated by heating at 90 and $120^{\circ} \mathrm{C}$. but retarded at the higher temperatures, which, however, increased the growth of fungi. They noted that heating increased acidity and suggest that this may account for the better growth of plants such as blueberry on "burned over" soils.

Lyon and Bizzell (63) have shown that when a soil has been heated to complete stcrility by steaming and subsequently maintained at a moisture content of 25 per cent of its dry weight, the total solids decrease rapidly, as shown in table $B$.

TABLE B

Effect of standing on the water-soluble constituents of heated soils

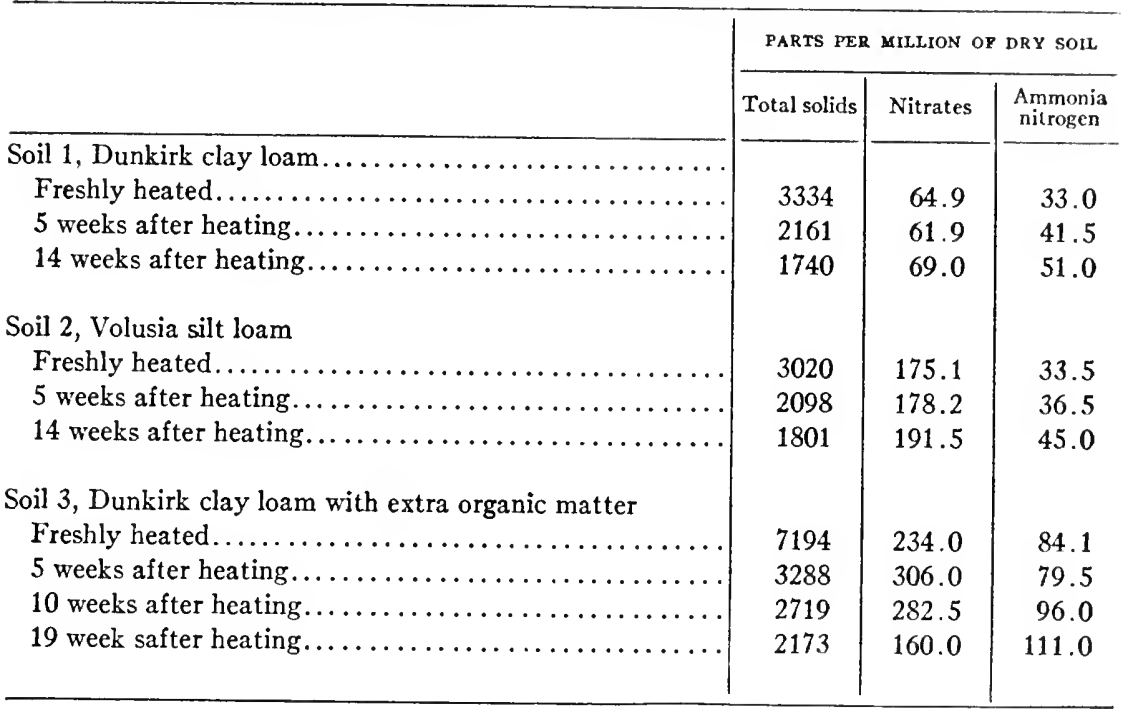

The nitrates have been affected but slightly, except in Dunkirk clay loam with extra organic matter, where there was an increase during first 5 weeks, but a rapid decline later, and, in general, an increase in ammonia nitrogen.

In another experiment, freshly heated soil had 1010 parts per million of total soluble solids and 246 parts per million of inorganic, while after 3 months the corresponding amounts are 590 parts per million of total soluble solids, and 126 parts per million of inorganic. When aerated during the 3 -month period, there is a further decrease to 434 and 120 parts per million, respectively.

Russell and Petherbridge (87) state that plants grown on soils heatcd at $100^{\circ} \mathrm{C}$., in comparison with unheated soils, have larger leaves of deeper green color and stouter stems, they flower earlier and more abundantly, the fruiting is more prolific, and they contain a higher percentage of nitrogen and sometimes phosphoric acid in their dry matter.

König, Hasenbäumer and Glenk (56) heated soil at $95^{\circ} \mathrm{C}$. in a vacuum, which, in most cases contained markedly more water-soluble organic matter as well as total soluble solids 
than did unheated soils. Heating at $150^{\circ} \mathrm{C}$. still further increased the solubility of both organic and mineral matter. In most comparisons, heating increased the amount of watersoluble phosphorus, yet a few gave slightly less. Pot experiments with oats showed that heating in a vacuum at 95 to $98^{\circ} \mathrm{C}$. increased the growtl.

Wilson (106) secured slightly increased growth of plants in soil heated at $95^{\circ} \mathrm{C}$, , but retardation at higher temperatures, the effect varying with the kind of soil and nature of crop grown.

Buddin (8) found the nitrate content, immediately after drying in a thin layer in laboratory for 24 hours, unaffected, but reducing the moisture content further during 46 hours did increase the nitrate content slightly. When the dried soils were remoistened and incubated for 40 days, there was a marked increase in nitrates; untreated moist soil 36 parts per million, soil spread in gallery 46 , and in glass-house 53.5 parts per million.

King (48) relates that the residents of northern China build flues ("Kangs") of sun-dried bricks made of "soil or subsoil mixed with short straw or chaff." After two to four years" use, these flues become defective, so that they must be replaced. When removed the bricks are finely pulverized and used as fertilizer, being planted in hills with the seed. The soil while used as a flue has become thoroughly air-dry and on the inside of the flue, undoubtedly, much of it has at times been freed of uncombined water. During this long-continued drying, the plant nutrients have been rendered more available and this fact is made use of by the Chinese farmer. King (47) suggests "absorption of the products of combustion" by the "brick" as an additional factor in giving them value as fertilizer.

Kelley and McGeorge (40) review briefly the history of burning soils. There are, in Hawaii, large areas of heavy soil which do not, when first plowed, produce satisfactory crops. It requires several months of cultivation before crops thrive. It has been noticed that on small spots where brush has been burned cotton grows exceptionally well. It is suggested that this effect may be due to heating the soil rather than to the soluble oxides of phosphorus, potassium, calcium and magnesium in the ash, since fertilizers do not produce such beneficial results.

They report results of analyses of the 1:5 water-extract of a brown ferruginous clay soil and its subsoil, and a similar type which had been plowed and was growing pineapples. Determinations were made on fresh, air-dried and oven-dried samples, extracted respectively for 1 hour, 24 hours and 7 days. Phosphoric acid $\left(\mathrm{P}_{2} \mathrm{O}_{5}\right)$ was always highest in the oven-dried soil, manganese oxide $\left(\mathrm{Mn}_{3} \mathrm{O}_{4}\right)$ always higher in air-dried than in fresh soil (not determined in oven-dried soil). Lime $(\mathrm{CaO})$ was highest in the oven-dried soil in three of nine comparisons only. Magnesia $(\mathrm{MgO})$ varied, in some samples higher in the air-dried. Sulfuric acid $\left(\mathrm{SO}_{3}\right)$ was highest in the fresh soil of tener than in either of the others, and potash was highest in the air-dried soil (with one exception) in the two surface soils, while in the subsoil the fresh soil held first place.

When all the comparable data are considered we see that in three cases the fresh soil was highest in total soluble solids, in three cases the air-dried and in the other three cases the oven-dried soil stood first. So no conclusion as to the effect of heating on total soluble salts can be drawn from these figures.

In general, extracting for 24 hours or for 7 days gave but slightly higher results than extracting for 1 hour, except in the case of phosphorus which increased in solubility with longer extraction. In two out of eight trials, heating at $100^{\circ} \mathrm{C}$. increased the nitrate content; in four soils it was decreased while in the other two there was no change. As the soil was raised to higher temperatures, 150 to 200 and 250 nitrates decreased rapidly until almost none was recovered at the highest temperature.

These investigators think both chemical and physical factors enter into an explanation of the effect of drying on the soluble constituents of soils, but that "the most important set of factors affecting the solubility of inorganic soil constituents are physical in nature. Also that the physical factors act through the effect of changes in soil moisture on the physical properties of the soil." "The conditions conducive to the formation of a colloidal state and 
the subsequent relation of heat to the destruction of this colloid are two of the most important of these factors." When soil contains some capillary or film water this moisture is distributed about the particles as a thin film varying in thickness with the quantity of water present in any given soil. It is stated that the moisture film in air-dry soils is held with a force equal to 10,000 atmospheres and that under such conditions "the concentration of film water with reference to the mineral matter should be much greater than that of the free or capillary water in the soil." They hold that air-dricd soils should, and their results are claimed to, show least solubility.

The films with organic and inorganic matter in solution may be looked upon as colloidal in nature. Upon heating to $100^{\circ} \mathrm{C}$. alteration in the film occurs through evaporation and by partial dehydration of the colloids, destroying the pressure by which the film was previously held around the particles. During evaporation the concentration of the soil moisture would increase to the saturation point, after which mineral matter would be deposited with further evaporation.

The solution obtained upon adding water to oven-dried soil should be of greater concentration than that from air-dried soil. With water films absent and the colloids altererl. the water has more ready access to the soil particles. They found some mineral constituents more soluble at $250^{\circ} \mathrm{C}$. than at $100^{\circ} \mathrm{C}$. and think it due to "more complete elimination of soil moisture and especially the water of chemical combination."

Hulett and Allen (37) showed that the concentration of the solution in equilibrium with a curved surface is greater than that in equilibrium with a plane surface and that gypsum is most soluble in water at $40^{\circ} \mathrm{C}$. Above $80^{\circ} \mathrm{C}$. it is less soluble than at $0^{\circ} \mathrm{C}$.

McGeorge (66) reports further results of heating soils in sunlight, in an oven for 2 hours at 80,110 and $165^{\circ} \mathrm{C}$, and in an autoclave for 1 hour at 10 pounds pressure. Onions and cowpeas showed detrimental effects while millet showed increased vigor with the higher temperature of sterilization. Heating gave better results than volatile antiseptics.

Ehrenberg (21) speaks of the old custom of using as fertilizer old garden walls made of soil and says that many soil workers have noted an improvement as the result of a soil drying out. He thinks soils rich in organic matter, only, are affected materially by drying.

Hall (27) allowed eight pots of similarly treated Dunkirk clay loam to dry from October 19 to March 1. At this time the moisture content of four pots was brought up to 20 per cent and held there until April 12. The other four continued to dry until March 19, at which time the moisture content was 1.8 per cent. The first four pots had an average of 847 part; per million (of dry soil) of total soluble solids and 5.18 parts per million of nitrates, while the average for the four air-dry soils was 1303 parts per million of total salts and 324 parts per million of nitrates, a marked increase due to drying. In October, a sample of the soil was dried. In March it had 1628 parts per million of total soluble-matter and 397 parts per million of nitrates. A sample of the original soil bottled at 12.2 per cent moisture in October had in March 1459 parts per million total salts and 495 parts per million of nitrates. This shows that nitrification had been active as in the soil which dried to March 1.

Klein (53) conducted experiments with Dunkirk clay loam (a) low in organic matter and (b) well supplied with organic matter, this being timothy sod which had been piled up and allowed to decay. Keeping soil $a$ at 15,20,25 and 30 per cent moisture and $b$ at these moisture contents with an additional sample at 40 per cent, gave an increase in growth of wheat on $a$ with a decrease in moisture, and the same general relation held for $b$ except that the soil with 40 per cent moisture gave practically the same yield as that with 15 per cent. There is no important difference in the yield of buckwheat following the wheat. Soil $a$, unplanted, contained more total soluble solids with the lower moisture contents, whilc soil $b$ showed an increase in total soluble solids with an increase in the water content. Nitrates decreascll with the lowering of the water content. Difference in water content had no effect on solubility of potassium, calcium and phosphorus in this soil. Air-drying reduccd the nitrates, but when later brought up to and kept at optimum moisture content for various periods greater than 16 days, the nitrates increased materially. The nitrifying power and power to produce carbon dioxide is, in general, affected in the same way. 
Wilson (105) found that heating at 60 to $150^{\circ} \mathrm{C}$. for 2 hours increased the amount of soluble natter and changed the physical condition so that its water-holding capacity was affected. Ile accounts for increased productivity on these grounds.

Buck (7) reports results of a study on the effect of heat on soils, by Mann who found the water-soluble constituents increased with the rise in temperature to which the soil was heated. He notes greater grow th of rice seed'ings immediately after heating, quite the reverse of his experience with other plants, which may be due to the ability of the rice seedling to withstand any harmful effects of, or to use in growth, the ammonia which many hold to be a result of heating.

The work of Kelley and Thompson (41) shows that nitrates undergo decomposition, gradually disappearing as the temperature is raised. Only slight decomposition took place at $100^{\circ} \mathrm{C}$. Steam heating at 2 atmospheres produced effects similar to those resulting from heating at $150^{\circ} \mathrm{C}$. without pressure.

Bonyoucos (5) heated sandy loam, loam, clay and peat at 15 atmospheres pressure in an autoclave for three hours, thereby increasing the water-soluble material, as shown by the depression of the freezing point, respectively, $75,50,190$ and 333 per cent.

In explanation of the effect of heat, he points out that water films in intimate contact with the soil particles are more concentrated than capillary or interstitial water, due to the slowness of diffusion. If only the capillary water is extracted, the quantity of soluble matter recovered would be less than the total actually in solution in the soil moisture. He suggests that adsorption may account for a ligher concentration at the immediate surface of the particles than in the bulk of the solution. Furthermore, there is wide variation in the solubility of the minerals composing the soil and because of the extremely slow rate of diffusion, different mineral particles would be enveloped by films of varied concentration. This, too, would interfere with recovering from moist soil all of the soluble material.

Allen and Bonazzi (2) quote Stevens and Withers showing "only about 40 per cent of the nitrates were recovered by $1: 3$ extraction when small quantities were added and more than twice this amount when larger quantities were added." Allen and Bonazzi recovered in the first extraction (1:5 with $100 \mathrm{gm}$. of soil) from 65.9 to 83.9 per cent of the nitrate added, or as an average of ten results reported, 77.4 per cent.

Potter and Snyder (78) report a recovery of 93 to 97 per cent of the nitrate added at the rate of 3 parts per million of soil (phenoldisulfonic acid method).

These authors (79) report complete extraction of nitrates when 1 part of soil is shaken with 2 parts of water for 30 minutes (aluminum reduction method).

Jolnson (38) reports preliminary results, showing that heating increased the solubility of minerals and the growth of plants. Heating to $250^{\circ} \mathrm{C}$. produced more water-extractable substance than lower temperatures.

Skalskij (95) in studying methods of sterilization heated soil in an autoclave for 1 hour at 2.5 atmospheres. Plants in this soil grew as well as those in soil receiving complete fertilization, the number of bacteria was greater than in the untreated soil, the inoculation coming from the air. The improved fertility was due to a large increase in the soluble phosphorus, from 47 to 121 per cent, and while the soluble nitrogen content was not affected by heating, the dark green color clearly showed an increase in the available nitrogen.

Connor (15) reports a reduction in acidity as a result of heating.

Coleman, Lint and Kopeloff (14) found that the soluble solids recovered by $1: 4$ extraction of a moist l'enn clay loam soil (25 per cent water on the dry basis) after intermittent partial sterilization at $82^{\circ} \mathrm{C}$. for 1 hour on each of 5 consecutive days, was increased 46 per cent, but the anount of soluble salts was not appreciably increased after the first day's heating. The air-dry soil ( 4.5 per cent moisture) when similarly treated showed no increase in watersoluble solids. Sterilization by moist heat at $120^{\circ} \mathrm{C}$. for 15 minutes at 15 pounds pressure increased the water-soluble solids recovered 0.0220 to $0.1805 \mathrm{gm}$., an amount 8.2 times as great as that recovered from the original soil. It should be noted also that volatile antiseptics amplied as vapor in a partial vacuum. increased the water-soluble solids in air-dry soil 22 per 
cent and 25 per cent in the moist soil. When the volatile antiseptics are applied with heat $\left(82^{\circ} \mathrm{C}\right.$.) and pressure, the amount of soluble solids in moist soil is increased 25 per cent.

Christensen (10) noted that air-dry soil had its power to liberate acid from calcium acetate considerably increased as compared with that of fresh moist soil.

Koch (54) determined the effect of sterilization on the concentration of the soil solution by means of the freezing-point method. Concentration was increased more in the heavy soils. Steaming was more effective than sterilizing with formalin. Using formalin 1:50 and steaming at 10 pounds pressure increased the concentration of the soil solution more than any other method used, in fact to three times the original concentration. In Sassafras and Penn loams it was increased, respectively, 0.24 and 0.3 atmospheres. Sterilization by the so-called "commercial" methods increased the concentration of the soil solution, varying with soil and method of sterilization. Heating with steam at 10 pounds pressure for 1 hour increased the concentration of the soil solution 0.56 atmosphere in a loam soil; with a Norfolk sand the increase was but one-fourth as great.

Stewart (96) studied water extracts of thirteen soils, of two distinct types both planted and fallow, finding as did King (44) that "poor" soils yielded extracts containing solids less soluble than solids in extracts from "rich" soils.

Hartwell and Pember (28) while investigating the effect of aluminum on barley and rye, compared unheated acid soil with samples heated at $100,260,360$, and $420^{\circ} \mathrm{C}$. The lime requirement was markedly reduced by heating and the reduction increased somewhat with the temperature. The weight of green tops of rye was reduced by heating except that heating at $420^{\circ} \mathrm{C}$. caused no difference in yield. The yield of green barley tops was decreased at both 100 and $260^{\circ} \mathrm{C}$. but increased at both of the higher temperatures.

Potter and Snyder (80) state that "the amount of ammonia was increased by all the heat treatments, the higher temperatures to which the soils were heated giving in general greater increases;" also that dry heating at $100^{\circ} \mathrm{C}$. did not materially affect nitrates, but at 10 pounds pressure in an autoclave for 9 hours, nitrates were markedly increased while a temperature of $200^{\circ} \mathrm{C}$. caused an almost total disappearance of nitrates.

Johnson (39) heated soil at $250^{\circ} \mathrm{C}$. The yield of tobacco was increased 571 per cent on muck, 473 per cent on Waukesha silt loam, 150 per cent on clay, 96 per cent on fine sandy loam and 62 per cent on virgin sandy loam. A single heating gave a larger yield than did heating two to eight times at $115^{\circ} \mathrm{C}$. He found, also, enormous increases in concentration of the soil extract, as shown by freezing-point determinations. Heating at $250^{\circ} \mathrm{C}$. caused the highest concentration.

He classifies under eight heads the published theories explaining the effect of sterilizing soils on plant growth, three of which have some bearing on the problem in hand; (a) "Modified organic compounds" as already mentioned from Schreiner and Lathrop (90). (b) "Modified inorganic soil compounds." This theory is supported by many investigations which show that an increase in inorganic plant nutrients occurs on heating soils. (c) "Physical theories." The author says the physical "theories are not subscribed to by any author in particular at the present time, although it was quite generally believed at one time that all the benefit derived from burning the soil was due to purely physical changes. Some of the physical factors which play a part in soil fertility are, however, coming to be regarded as very influential in conjunction with chemical factors."

Beaumont (3) showed that drying soil caused a decrease in the amount going into suspension in distilled water or 4 per cent ammonia. Oven-drying soils and then putting them under water logged conditions increased the quantity of iron compounds soluble in dilute hydrochloric acid. He states, also, that "sterilization checked the formation of this easily soluble colloidal material."

Noyes (70) while working with adsorption of difierent radicals by soils and decaying leaves. detected no adsorption of nitrates. He holds "nitrates are completely recovered from soil in one extraction by water, and nitrates added to soil are completely recovered in addition to those present in the soil." He noted also that the lime requirement of a residual limestone soil was higher when not heated than when cvaporation is carricd on in the usual way. 
Robinson (84) states that the lime requirement of soils, as shown by the Veitch method, is affected by $(a)$ "the temperature at which evaporation is made," $(b)$ continued heating after soil is dehydrated, $(c)$ length of time during which treated and dried soil is in contact with water, and $(d)$ the source of heat, such as steam or sand bath or hot plate.

An enormous amount of interesting work on the soluble-solid content of soils under many different conditions of cropping is reported by King (42, 43, 44, 46), King and Jeffery (49), King and Whitson $(50,51,52)$ and Whitson (104).

The literature of drying, heating and sterilizing soil has been quite extensively reviewed by Lyon and Bizzell (62) and (63), Schreiner and Lathrop (90), Kelley and McGeorge (40), Klein (53), Hall (27), Kopeloff and Coleman (57), Stewart (96), Beaumont (3) and Johnson (39).

\section{SUMLMARY OF LITERATURE}

1. Heating soil in various ways for its beneficial effect on crops is an ancient practice.

2. For several decades past, commercial greenhouse men have sterilized the soil used, to kill detrimental organisms, and have noted beneficial results other than from sterilization, particularly increased growth of leaves and stems.

3. Much careful experimental work on heating and drying soils has been reported, both before soil organisms were recognized, and in connection with soil-biology studies, which shows that drying and heating soil at $100^{\circ} \mathrm{C}$, , or higher, increases its productiveness, even though germination may be retarded and early growth depressed.

4. The literature shows that the quantity of soluble mineral and organic constituents recovered by extraction with distilled water is increased by heating. The increase bears some relationship to the temperature of heating, the maximum of soluble constituents being found at about $250^{\circ} \mathrm{C}$, above which the total salts recovered decreases.

5. Investigators are not in general agreement as to the effect on nitrates of heating at $100^{\circ} \mathrm{C}$. Many workers note a decrease as the temperature is further raised and almost total disappearance of nitrates at $250^{\circ} \mathrm{C}$.

6. Soil workers are not a unit as to the cause of the increase in soluble material due to drying and heating. Some hold the effect of heating to be largely physical; others that it is mainly chemical, and still others lay most stress on the biological phase. Nearly all admit that the physical is usually a factor and others add colloids as a physio-chemical factor.

7. There is wide variance of opinion as to the degree to which nitrates are recovered by one or more extractions.

\section{EXPERIMENTAL WORK}

\section{Introduction}

While the literature shows that an enormous amount of work has been done on the effect of heating at a wide range of temperatures and under varied moisture contents on the amount of soluble constituents of soils, it was considered desirable to study the effect of drying at $105^{\circ} \mathrm{C}$. for 8 hours, the ordinary method of driving of so-called hygroscopic moisture, on the total soluble solids that may be recovered by $1: 5$ extraction with distilled water. 


\section{Method of collecting soil}

The surface vegetation was removed and the surface of the soil leveled. Steel tubes of $2 \frac{1}{2}$ inches inside diameter at the cutting edge and 25 inches above it were used. A block of wood was placed on the tube which was then driven into the soil with a sledge hammer to a depth of 8 inches. The soil within the tube constituted the "tube" surface sample. IIeavy paper held in place by rubber bands was immediately placed over each end of the tube to reduce evaporation and aeration.

A sample was then collected from immediately around the tube with a $1 \frac{1}{2}$-inch auger to the same depth. This was immediately placed in a 2-quart Mason jar with a minimum of evaporation and aeration. This was the "auger" surface sample.

The hole was enlarged and dug out with a spade to a depth of 12 inches and the soil from 8 to 12 inches discarded. The tube was driven down from 12 to 20 inches and protected as before. This stratum 12 to 20 inches constitutes the "tube" subsurface sample. The "auger" sample was collected and sealed as before. All samples were taken to the laboratory. The paper cap at the top of the steel tubes was removed and melted paraffin poured on so as to seal it. When the paraffin had solidified, the tubes were inverted, a portion of the soil removed and the tube sealed as above. Both tubes and jars were properly labeled and placed in a refrigerator, at a temperature of 8 to $12^{\circ} \mathrm{C}$. in order to keep the soil as nearly in its original condition as possible by minimizing biological activity.

All soil samples were collected and treated in this way.

\section{General procedure}

Duplicate 100-gm. samples were weighed into aluminum dishes of known weight and placed in an electric oven at a temperature of about $105^{\circ} \mathrm{C}$. for 8 hours to determine the total moisture. After these had been weighed, water-free soil from another dish was added to each to make exactly $100 \mathrm{gm}$. of water-free soil for the determination of total soluble salts and nitrates.

Lyon and Bizzell (63) have shown that aerating after heating has a marked influence on the disappearance of total soluble solids. For that reason, all soils both before and after heating were kept in closed containers to reduce aeration to a minimum.

The percentage of moisture in the fresh soil was calculated on the basis of water-free soil as 100 per cent. The method of obtaining a quantity of moist soil precisely equivalent, to $100 \mathrm{gm}$. of water-free soil, was to add to $100 \mathrm{gm}$. of moist soil $1 \mathrm{gm}$. of moist soil for every per centum of moisture in it. King's (45) method was followed throughout. Five hundred cc. of distilled water was used with $100 \mathrm{gm}$. of water-free soil. The soil was placed in a mortar, sufficient water added to make a thin paste, rubbed with a pestle for 3 minutes, and the mixture transferred to a porcelain pitcher, stirred a moment, and allowed to stand 20 minutes. Soil and water were then transferred to a Pasteur-Chamberland filter and a pressure of 15 to 20 pounds applied.

In the case of moist soil containing, for example, 20 per cent water, $480 \mathrm{cc}$. of water was added, making a total of $500 \mathrm{cc}$. precisely the same as in case of the dry soil. In this way, the calculation is simplified and the comparison is more accurate than where $100 \mathrm{gm}$. of both moist and water-free soil are used and $500 \mathrm{cc}$. of water added to each. For example, if 100 gm. soil contains 20 per cent water, only $80 \mathrm{gm}$. of soil are washed, $500 \mathrm{cc}$. $+20 \mathrm{gm}$., or cc., of water from the soil, a total of $520 \mathrm{cc}$. The ratio of soil to water is $1: 6.5$, instead of $1: 5$, as with $100 \mathrm{gm}$. of dry soil to $500 \mathrm{cc}$. of water, for which our plan calls.

The first $50 \mathrm{cc}$. of the soil extract was discarded. Two 125-cc. portions from each of the duplicate soil samples, or four portions from each soil, were placed in silica dishes and reduced to dryness on a water-bath, dried in the electric oven at $105^{\circ} \mathrm{C}$., cooled in a desiccator, and weighed on an analytical balance. This weight of solids represents onefourth of what was actually dissolved in the extract from the original $100 \mathrm{gm}$. of soil. 
For determining nitrates, two 50 -cc. samples from each soil duplicate, four in all from each soil, were evaporated to dryness, after adding a few drops of a saturated solution of sodium carbonate, and nitrates determined colorimetrically according to Schreiner and Failyer (89).

\section{Experiment 1}

The object of this experiment is to study the effect of oven-drying on the soluble solids and nitrate content of four types of soil found in this locality and which cover a wide range of physical composition.

Samples of four soils were collected October 24, 1918, from the Station farm at Ithaca.

1. Dunkirk sill loam

A. Surface, yellow, heavy silt to clay loam

B. Subsurface, yellow silt loam

Both surface and subsurface soil contained a few small pebbles and were very low in organic matter. This soil had been growing a heavy sod of Kentucky bluegrass for the past ten years.

2. Genesee gravelly loam

A. Surface, brown gravelly loam, much coarse material

B. Subsurface, yellowish brown gravelly loam to gravel

This was a very coarse gravelly loam containing only a small percentage of sand, little more than a trace of silt and clay, and was low in organic matter. It had been growing alfalfa and some Kentucky bluegrass for several years.

3 Dunkirk fine sandy loam

A. Surface, yellow fine, sandy loam

B. Subsurface, yellow sandy loam, sand below 18 inches

The first 18 inches of this soil were very uniform in texture. The land was naturally not well supplied with organic matter, but had been manured somewhat in recent years. It had been fallowed during 1918 and was being planted to young orchard.

4. Volusia stony loam

A. Surface, brown stony loam, loamy phase, not many stones in sample

B. Subsurface, yellowish brown stony loam, more fragments of stone than in surface. This sample was taken near the boundary between this type and Volusia silt loam as mapped by Bonsteel, Fippin and others (4). This soil has been growing mixed grasses for some time.

Table 1 gives the results of the determinations of total soluble solids and nitrates in heated and unheated soils. The figures in the last column of tables $1,2,3$ and 6 are in each case the product of the probable error of the difference and 3.81. It is the quantity of total solids in milligrams that the dry soil must exceed the moist (or air-dry) in order that the variation may be considered significant, that is, that the odds be $30: 1$ in favor of the difference being due to variation in the conditions of the experiment and not to error in manipulation.

From table 1, it is readily seen that in every case the dry soil yielded more total soluble solids than did the moist soil. The amount of nitrates varies considerably. In five of the eight tube samples, denitrification had reduced the nitrates to zero, of the remaining eleven comparisons, the moist soil was slightly higher in nitrates in six, while the dry was ahead in five cases, so no conclusion as to effect on nitrates can be drawn from this experiment. It 
should be stated that there was considerable variation in the period between sampling and the determination (the last one being made August 15,1919) so that biological action may account in part for the wide variations and the frequent high probable error of the difference. Occasionally the ice was allowed to get low in the refrigerator so the temperature became high enough for good bacterial growth. There is, however, no case in which, if the nitrates are calculated as $\mathrm{Ca}\left(\mathrm{NO}_{3}\right)_{2}$ and deducted from the total solids, that the conclusion or its significance is altered.

\section{Experiment 2}

The purpose of this experiment was to study the effect of storage for nine weeks at 8 to $12^{\circ} \mathrm{C}$. on the quantity of soluble material when the soils were kept under somewhat carefully controlled conditions of moisture content, but under different conditions of aeration. Determinations of total soluble solids were made on both moist and dry soils.

On October 23, 1919, three soils, Dunkirk silt loam (sod), Dunkirk silt loam (stony), and Dunkirk sandy loam, were collected and treated as noted above. The first and third are the same soils as were used in experiment 1 and are similar to them in every way, these samples being taken within a few feet of the others. The third soil, Dunkirk silt loam (stony), was taken from a field growing rye and vetch. It had been well manured before seeding and has received considerable fertilizer during the past few years.

\section{Procedure}

The tube samples were sealed with paraffin at once and kept in the refrigerator for a period of 68 days to determine the effect of this method of storage. The jars containing the auger samples were kept in the refrigerator also. Total soluble solids and nitrates were determined on all of the auger samples within the next 5 days, beginning on October 24 .

The remainder of each of these samples was kept in the ice-box in an open jar to allow free aeration, weighed at intervals of 1 week, and distilled water added to make up for any loss by evaporation in order to detemine the effect of this method of storage for 65 days. The principal difference in the two methods of storage is in the opportunity for aeration in the auger sample in open jars, particularly since the water evaporating was compensated at intervals of one week.

The results of the determinations are stated in table 2 .

These figures show that the oven-dried soil compared with the original moist soil had in the two silt loams three to five times as much soluble solids and in the sandy loam twice as much.

The Dunkirk silt loam (sod) contained very little soluble matter, either mineral or organic, and but little more than a trace of nitrates, 1.7 parts per million in the fresh moist sample. This is in close accord with determinations made on this soil collected the previous season, though both nitrates and total solids were somewhat higher then. 
A. F. GUSTAFSON

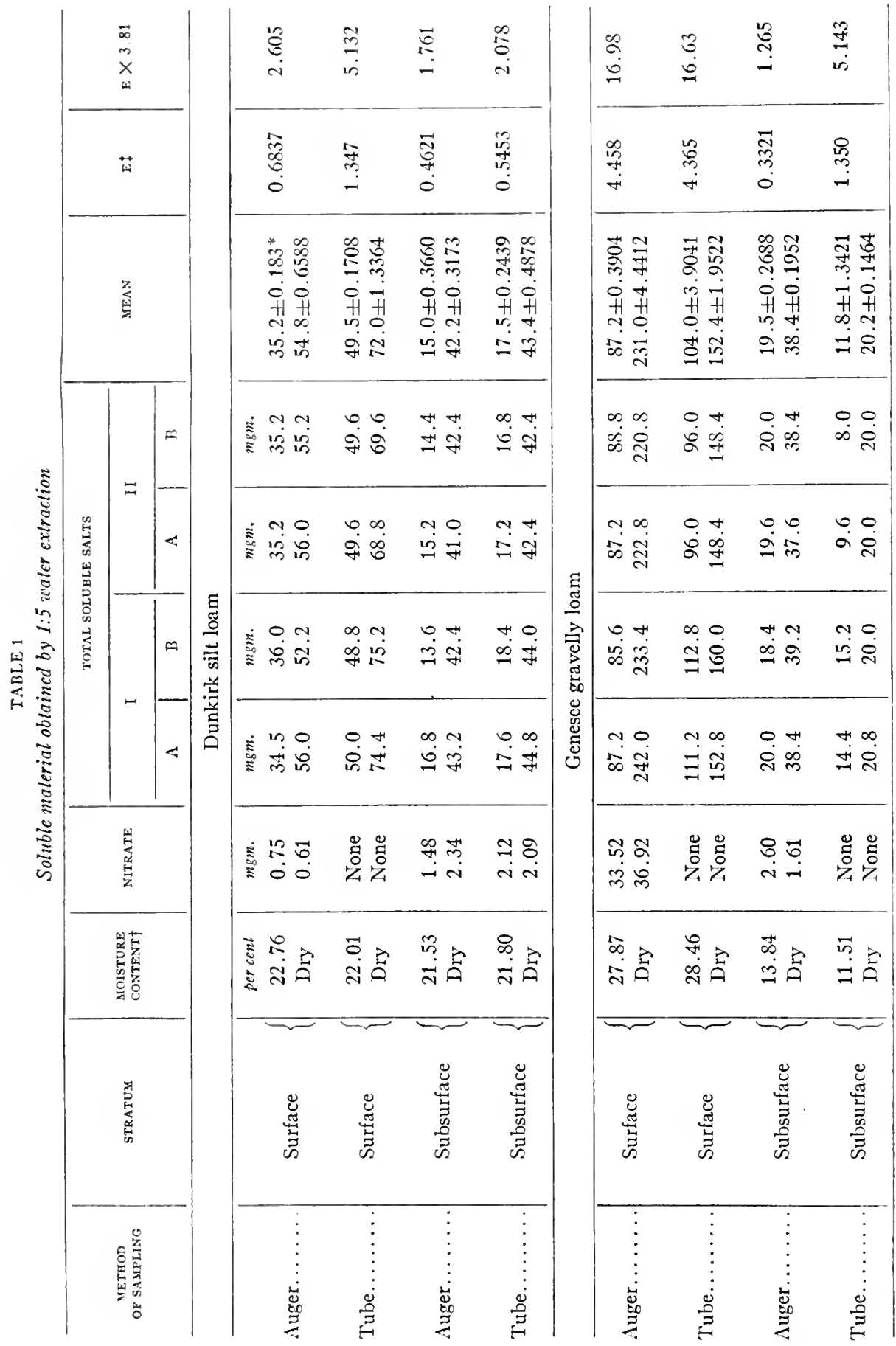




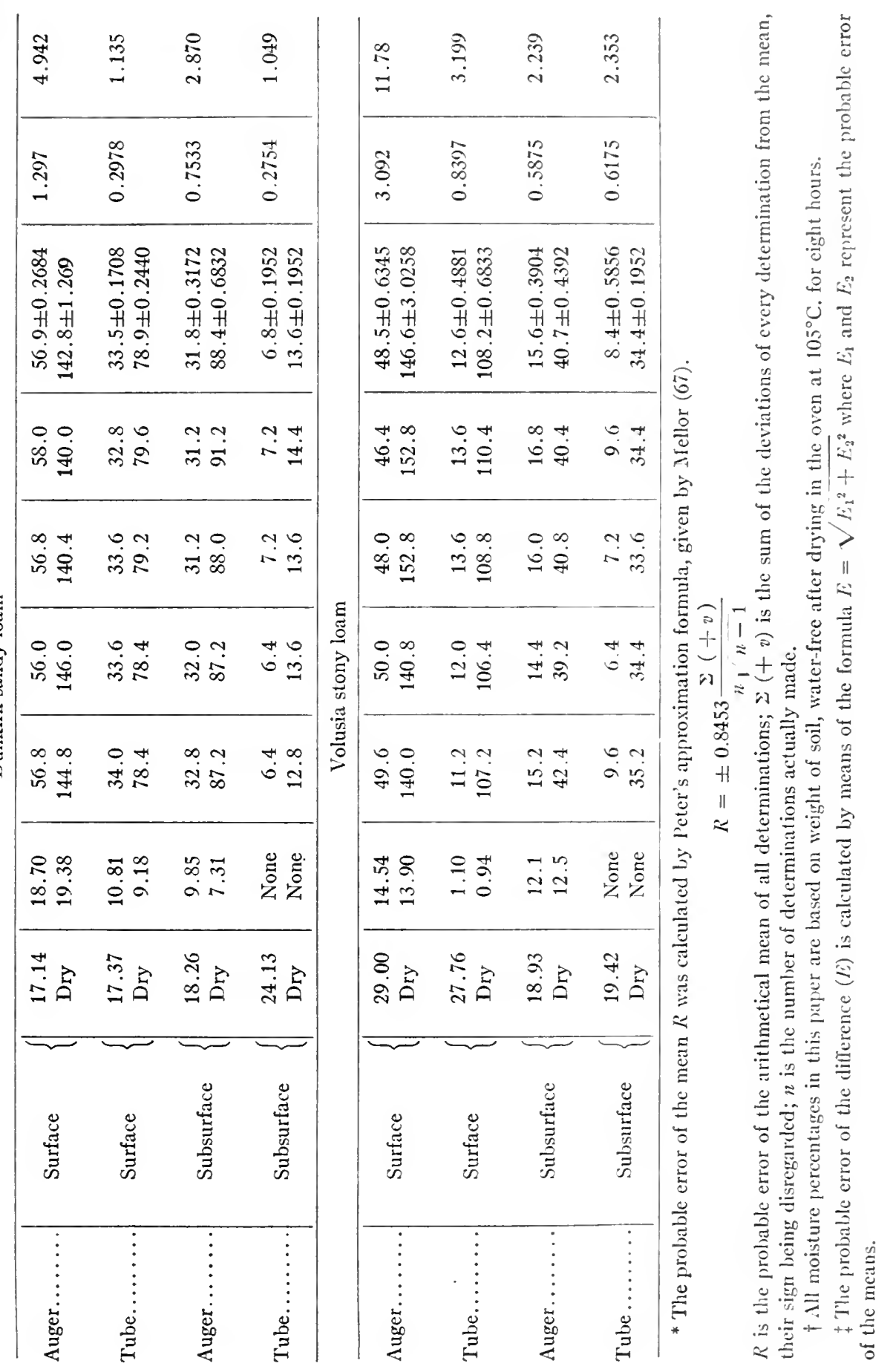


A. F. GUSTAFSON

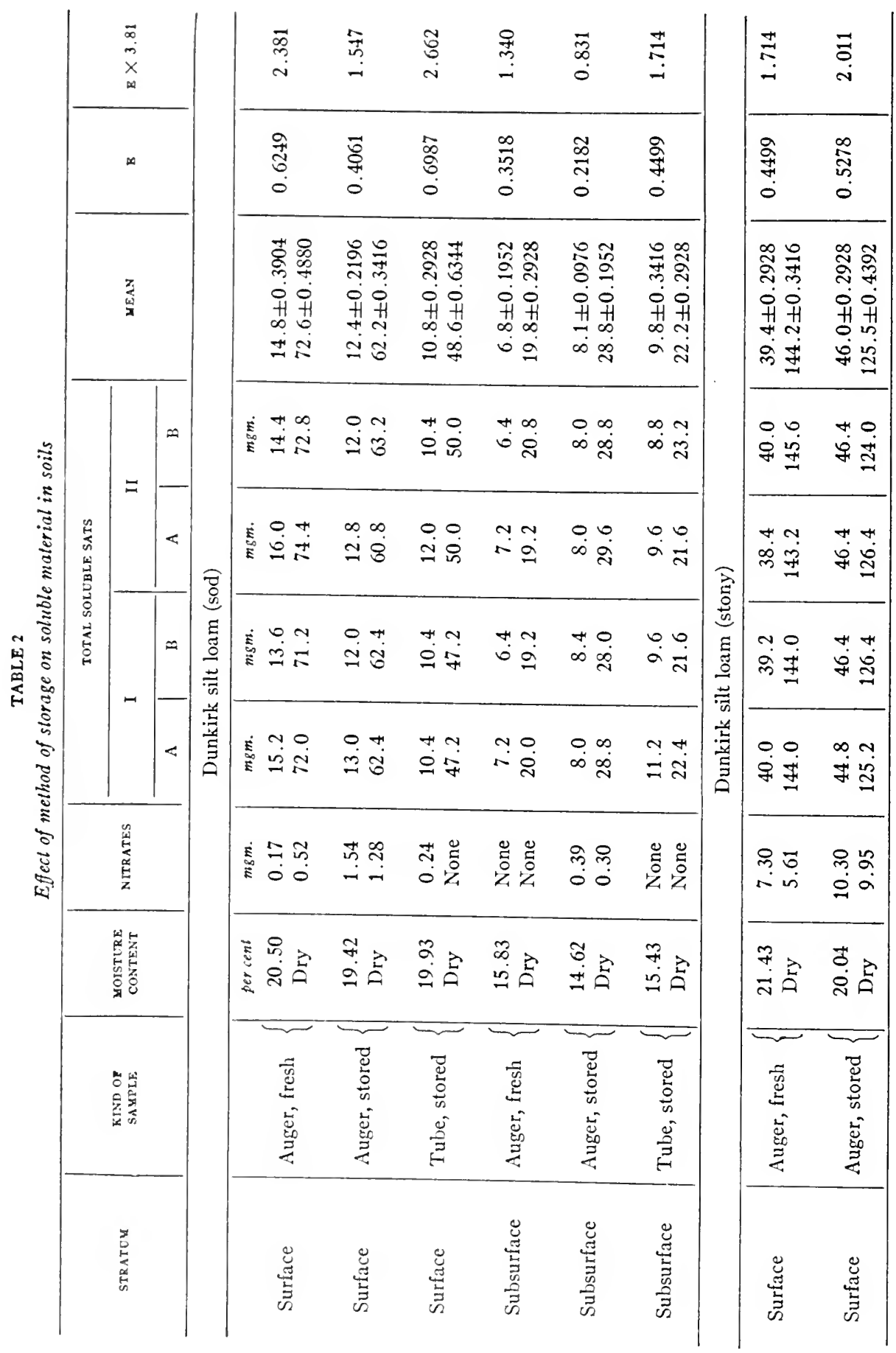




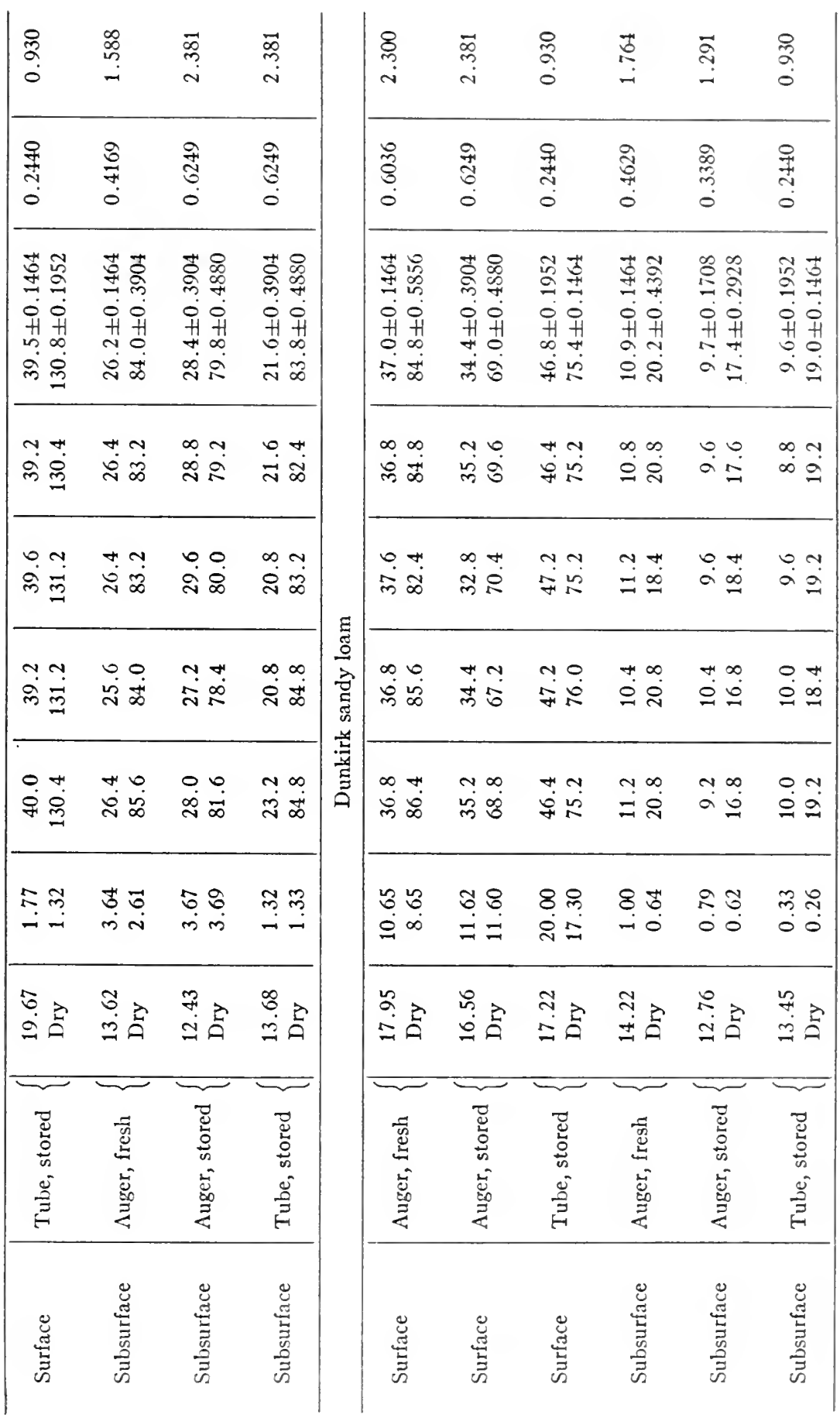


Close scrutiny of this table reveals that in three cases the stored auger sample is higher in total soluble solids and in three cases, lower than the fresh sample. Determinations made on fresh auger samples and on the stored sealed-tube samples, therefore, are comparable.

In each soil there is evidence of nitrification in the open-jar-auger sample, the increases in the three soils being in order from 1.7 to 15.4 parts per million from 73 to 103 and from 106 to 116 . In some cases the nitrates run higher in the sealed-tube soil and in some lower than in the fresh soil, so from these meagre data no conclusion can be drawn as to the effect on nitrates of storing in sealed tubes for a period of 68 days.

It appears that the effect of storing at a temperature of 8 to $12^{\circ} \mathrm{C}$. in open jars for 68 days with the restoration of moisture evaporated at intervals of a week or in sealed tubes for 65 days does not materially affect the quantity of total soluble solids as determined by 1:5 extraction with distilled water, all of the soils being in the moist state. Storing decreased the soluble solids as determined in the water-free condition in five of the six comparisons made, the losses, however, were not great.

\section{Experiment 3}

The object of this experiment was to study the effect on soluble solids and nitrates of sun-, air- and oven-drying on soils that had been water-logged for a considerable period, if, indeed, ever dry since their formation.

In July, 1919, samples of a drab silt loam were collected near Cayuga Lake close to the west wall of the valley at the mouth of a small tributary. The surface and subsurface were taken with a steel tube, described above. The subsoil, 20 to 40 inches, was taken with an auger in the bottom of holes left by the tube after taking subsurface stratum. The soil suffered little, if any, change due to aeration and since it was very wet, containing 73 to 108 per cent of moisture, and the glass containers were sealed as soon as possible and placed in the ice-box on reaching the laboratory.

Determinations were made the same as in experiment 1 during the next few days on the wet and corresponding oven-dry samples and in the same way on the sun-dried samples on August 8.

Another set of samples was collected on October 16, 1919, south of Ithaca, near the east wall of the valley at the mouth of a small stream. This soil, also a drab silt loam, was not so wet as the other and contained nitrates in the subsurface, whereas the other soil had none in the subsurface.

In every case the wet soil was mixed thoroughly by hand and the total moisture determined in triplicate instead of in duplicate, as with all other soils.

The "wet" samples were oven-dried during the night and determinations made the following day, October 17 . Half of the soil was set out to dry in the laboratory, as there is usually not much sunshine and rainfall is frequent here at this season. Determinations were made as soon as the soil was entirely air-dry.

The results are given in table 3. 
It will be noted that oven-drying materially increased the total soluble solids in all of the wet samples, air-drying brought about a marked increase and oven-drying the air-dry soil still further increased the total soluble solids, as shown in table 4 .

In the first two columns of percentages, the increase is based on the total soluble solids in wet soil but in the third, the percentage increase is based on the total soluble solids in the air-dry soil. This increase calculated on the same basis as the first two is, for the respective samples, 83, 177, 290, 223 and 534 per cent. The increase due to air-drying before oven-drying cannot be due to any nitrification during the slow drying at ordinary temperature, as the increase in nitrates was exceedingly slight, wholly insufficient, calculated as $\mathrm{Ca}\left(\mathrm{NO}_{3}\right)_{2}$ to account for the change.

The marked effect of air-drying on these swamp soils may help to account for the relatively high productivity of such soils after a few seasons of cultivation, as against their low productivity when newly turned by the plow.

TABLE 4

Increase in total soluble salts due to drying

\begin{tabular}{|c|c|c|c|c|}
\hline sorl & STRATUM & $\begin{array}{l}\text { INCREASE } \\
\text { DUE TO } \\
\text { OVEN-DRY- } \\
\text { ING WET } \\
\text { SOIL }\end{array}$ & $\begin{array}{c}\text { INCREASE } \\
\text { DUE TO } \\
\text { AIR-DRYING } \\
\text { WET SOIL }\end{array}$ & $\begin{array}{c}\text { INCREASE } \\
\text { DUE TO } \\
\text { OVEN-DRY- } \\
\text { ING AIR-DRY } \\
\text { SOIL }\end{array}$ \\
\hline \multirow{4}{*}{ Drab silt loam near lake } & & per cent & percent & per cent \\
\hline & Surface, 0 to 8 inches & 60 & 23 & 50 \\
\hline & Subsurface, 12 to 20 inches & 62 & 74 & 59 \\
\hline & Subsoil, 20 to 40 inches & 200 & 94 & 104 \\
\hline \multirow{2}{*}{$\begin{array}{l}\text { Drab silt loam south of } \\
\text { Ithaca }\end{array}$} & Surface, 0 to 8 inches & 167 & 50 & 116 \\
\hline & Subsoil, 12 to 20 inches & 412 & 150 & 154 \\
\hline
\end{tabular}

Kelley and McGeorge (40) state:

The solubility of soils used in aquatic agriculture is abnormally high, but upon drying out these become much less soluble and approach a state similar to that existing in aerated soils. When such soils are heated after drying, they seem to undergo changes of the same order as are produced in dry-land (ordinary cultivated) soils.

The work here reported, cither experiment 3 or 4 , is not in accord with their conclusions, as these soils when air-dried, had, in every case, more soluble salts than the same soils when wet.

\section{Experiment 4}

The object of this experiment was to study the effects of oven-drying on a wide range of fine-grained soils containing varied amounts of organic matter at three moisture-contents, viz., air-dry, optimum, and water-logged, with the soil kept in the latter two conditions for a period of 9 weeks.

Six soils were used, ranging in texture from clay to sandy loam: 
1. Drab, ${ }^{3}$ or $\left(\right.$ Sharkey,$\left.{ }^{4}\right)$ clay. This is a drab colored clay soil, not well supplied with organic matter, stiff and more or less impervious to water, very dificult to work as it is exceedingly tenacious when wet and cloddy when dry. It occurs in large areas in the poorly drained portions of the Mississippi bottom lands, especially south of St. Louis. It is more fully described by Hopkins, Mosier and associates (34), Marbut and associates (65), and as Yazoo clay by Coffey and others (11).

2. Black clay loam ${ }^{5}$ (Marshall black clay loam). This is a black clay loam soil, well supplied with organic matter. It occurs in flat, depressed areas, former ponds or lakes, and is very productive when thoroughly drained. It is described more fully by Hopkins, Mosier, et al. (33), Marbut (65) and as Miami black clay loam by Coffey, Mosier et al. (12).

3. Brou'n sill loam (Marshall silt loam). This is a brown silt loam soil of good open texture, well supplied with organic matter, and very productive, occupying the rolling prairies of Illinois, Indiana and Iowa. Described by Hopkins, Mosier et al. (35), Marbut (65) and Coffey et al. (13).

TABLE 5

Organic matter* contained in these soils

\begin{tabular}{|c|c|c|c|}
\hline soIL & $\begin{array}{l}\text { ORGANIC } \\
\text { CARBON }\end{array}$ & $\begin{array}{l}\text { TOTAL } \\
\text { ORGANIC } \\
\text { MATTER }\end{array}$ & $\begin{array}{l}\text { MOISTURE } \\
\text { EQUIVALENT }\end{array}$ \\
\hline & percent & percent & percent \\
\hline 1. Drab clay... & 2.07 & 3.57 & 41.6 \\
\hline 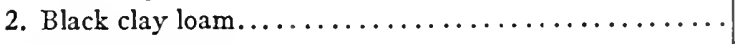 & 3.19 & 5.5 & 32.4 \\
\hline 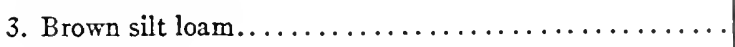 & 2.78 & 4.8 & 28.0 \\
\hline 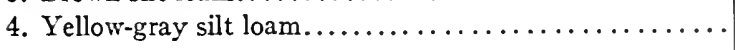 & 1.67 & 2.9 & 20.7 \\
\hline 5. White silt loam.. & 0.435 & 0.75 & \\
\hline 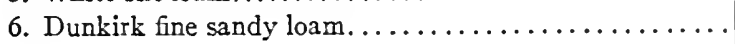 & $1.856 \dagger$ & 3.20 & \\
\hline
\end{tabular}

* Figures on soils 1 to 4 furnished by Professor J. G. Mosier.

† This determination was kindly made by Dr. F. A. Carlson.

4. Yellow-gray silt loam (Knox silt loam). This is a light colored, rolling timber soil, not well supplied with organic matter. More fully described by Hopkins, Mosier et al. (33), Marbut (65) and as Miami silt loam by Coffey, Mosier and others (13).

5. White silt loam. This soil was not recognized as a separate type by the Bureau of Soils, as its work in Illinois was done during the beginning of American soil surveying. It is a very light gray silt loam, underlaid by a decidedly impervious stratum, known as "tight clay." It is an unproductive virgin timber soil, very low in organic matter, in fact almost nitrogen free, having but 0.7 per cent of organic matter. This soil is more fully described by Hopkins, Mosier et al. (32).

6. Sandy loam. This is the same soil that was used in experiments 1 and 2 .

Soils 1 to 5, inclusive, are surface soils, 7 to $\delta$ inches deep. Soils 1 to $t$ have been stored in the air-dry state for two or more years in an attic where the humidity is very low and the temperature at times in summer, rather high.

Table 5 gives the content of organic matter in these soils.

2 Name used by Illinois Agricultural Experiment Station.

4 Name used by United States Bureau of Soils, in Bul. 96, p. 738.

${ }^{5}$ Soils 1 to 5 , inclusive, were collected by the writer while a member of the staff of the Agronomy Department, College of Agriculture, University of Illinois. 
Organic carbon was determined by the Parr bomb-calorimeter method, $\mathrm{CO}_{2}$ was measured and reduced to standard $P$ and $T$ from which $C$ was calculated. $C \times 1.724$ (Wolff factor) gives organic matter. This is not claimed to be absolutely accurate nor strictly comparable since the carbon content of soil organic matter varies with its age and the conditions under which decomposition has occurred. The organic matter in white silt loam, for example, is probably more highly carbonized than that in brown silt loam and that in drab clay, a swamp soil, has been affected by a different type of decomposition from brown silt loam, a well-drained type. However, the figure for organic matter is of value in a comparative way when, as in these soils, the differences between them are marked.

\section{Procedure}

The soils were air-dried, worked over with a rolling pin, passed through a $2-\mathrm{mm}$. screen, thoroughly mixed and divided into three portions, $a, b$, and $c$. On samples of $a$ the usual determinations of total soluble solids and nitrates were made in the original air-dry and in the water-free condition. To $b$ distilled water was added, and worked by hand, until it reached what might be termed "optimum" moisture content when the soil was placed in 2-liter earthenware jars. These were weighed on a solution scale the next day and at the end of each succeeding 7-day period, when distilled water was added to restore that lost by evaporation. To $c$, in similar jars, distilled water was added to a point of saturation and more water was poured on as needed to keep the soil submerged. Then $b$ and $c$ were kept in the laboratory for nine weeks, except the Dunkirk sandy loam which was kept only 8 weeks. The regular determinations were made on both moist and water-free samples at the end of this time.

Results are given in table 6.

Table 6 has several outstanding features. The increase in total solids extracted from soils 1, 2 and 3, well supplied with organic matter, when the original air-dry soil is dried in the oven at $105^{\circ} \mathrm{C}$. is very marked; in soils 4,5 and 6 , low in organic matter, the actual increase due to drying is less, but the amount of soluble solids varies from nearly twice to almost three times as much as that in the air-dry soil. In all, except white silt loam, which is very low in organic matter, the moist $b$ samples kept 9 weeks at optimum moisturecontent had a higher quantity of soluble material than did the air-dry soil, and the dry $b$ soil exceeded that water-freed directly from the original air-dry condition. This increase may be accounted for by the increase in nitrates, calculated as $\mathrm{Ca}\left(\mathrm{NO}_{3}\right)_{2}$.

The saturated $c$ samples in the wet condition showed more total soluble salts than either of the others, even though the nitrates had disappeared. When oven-dried, this soil showed the highest soluble salt content in five of the six soils, and the sixth was but $0.8 \mathrm{mgm}$. below the next higher soil, the water-freed, moist Dunkirk sandy loam. This may be accounted for in part by the very large amount of water in these soils shown in table 6 to be 75.7 per cent in drab clay down to 37.8 per cent in Dunkirk sandy loam. Here the soil solution is much more dilute and more solids tend to dissolve, as the 
solution is probably far from saturated with respect to any of the salts. This soil solution upon adding distilled water to make up the total $500 \mathrm{cc}$. becomes a part of the $500 \mathrm{cc}$. and the final result is a more concentrated solution as shown by table 6 . When the saturated soil was placed in the oven, water stood on its surface, so the oven-drying process required more than the usual 8 hours. This, it has been suggested, brings more organic matter and much iron and alumina into solution.

\section{Experiment 5. Determination of hygroscopic coefficient}

In the hope of securing information which might shed a bit of light on the cause of the increase in soluble material in soils due to heating, two small pieces of experimental work were undertaken, viz. (experiment 5), the determination of the hygroscopic capacity, or coefficient, of the soils used in experiment 4 and (experiment 6) a study of the retention of potassium nitrate by different grades of sand.

The soils are those used in experiment 4 which range from clay to sandy loam.

\section{Procedure}

In order to have the soils as uniform as possible, they were passed through a $1-\mathrm{mm}$. sieve. Duplicate samples of air-dry soil equivalent to approximately $2 \mathrm{gm}$. of water-free soil were weighed directly into weighing bottles, $7 \mathrm{~cm}$. in diameter. The soil was spread out in a uniformly thin layer over the bottom and exposed to a saturated atmosphere in a humidifier. ${ }^{6}$ Strips of filter paper were used as wicks, increasing the surface of contact between air and water in order to insure complete saturation of the air. By means of a water-pump the air pressure within the humidifiers was reduced by several centimeters in order to hasten saturation and reduce condensation. To avoid marked sudden changes in temperature, the humidifiers were placed in a thick-walled wooden box lined with asbestos. This was first located in a cold room and heated electrically, a thermostat being used for maintaining a constant temperature. It was found after 6 weeks' work, however, that the external temperature of winter varied so much that the thermostat and heating apparatus were incapable of maintaining a sufficiently constant temperature. In several instances there was a sudden drop in outdoor temperature the day before weighings were to be made. This brought about condensation in the soil, giving hygroscopic coefficients too high and far from uniform.

The next step was to place the entire apparatus in a deep, unheated basement room. Here the temperature to which the soils were subjected remained fairly constant. The maximum variation in room temperature during the first week was from 61 to $64^{\circ} \mathrm{F}$., and inside of the box from 15.5 to $17^{\circ} \mathrm{C}$; the second week the corresponding temperatures were 60.5 to $65.5^{\circ} \mathrm{F}$. for the room and from 15 to $18^{\circ} \mathrm{C}$. inside the box. There did not appear to be any condensation and yet there is not an altogether satisfactory agreement of duplicate determinations made the first week on soils 4,5 and 6 .

The soils were kept in the saturated atmosphere for a period of 7 days when the humidifiers were removed from the constant-temperature box. Before removing the lid of humidifiers, the pressure was equalized by admitting air very slowly through the side tube. Upon removing the weighing bottles from the humidifier, the lids werc immediately and tightly inserted

${ }^{6}$ The humidifier was a large desiccator whosc dehydrating substance had been replaced by a 10 per cent solution of sulfuric acid to furnish the water vapor. The desiccators are supplied with side tube and stop cock. 


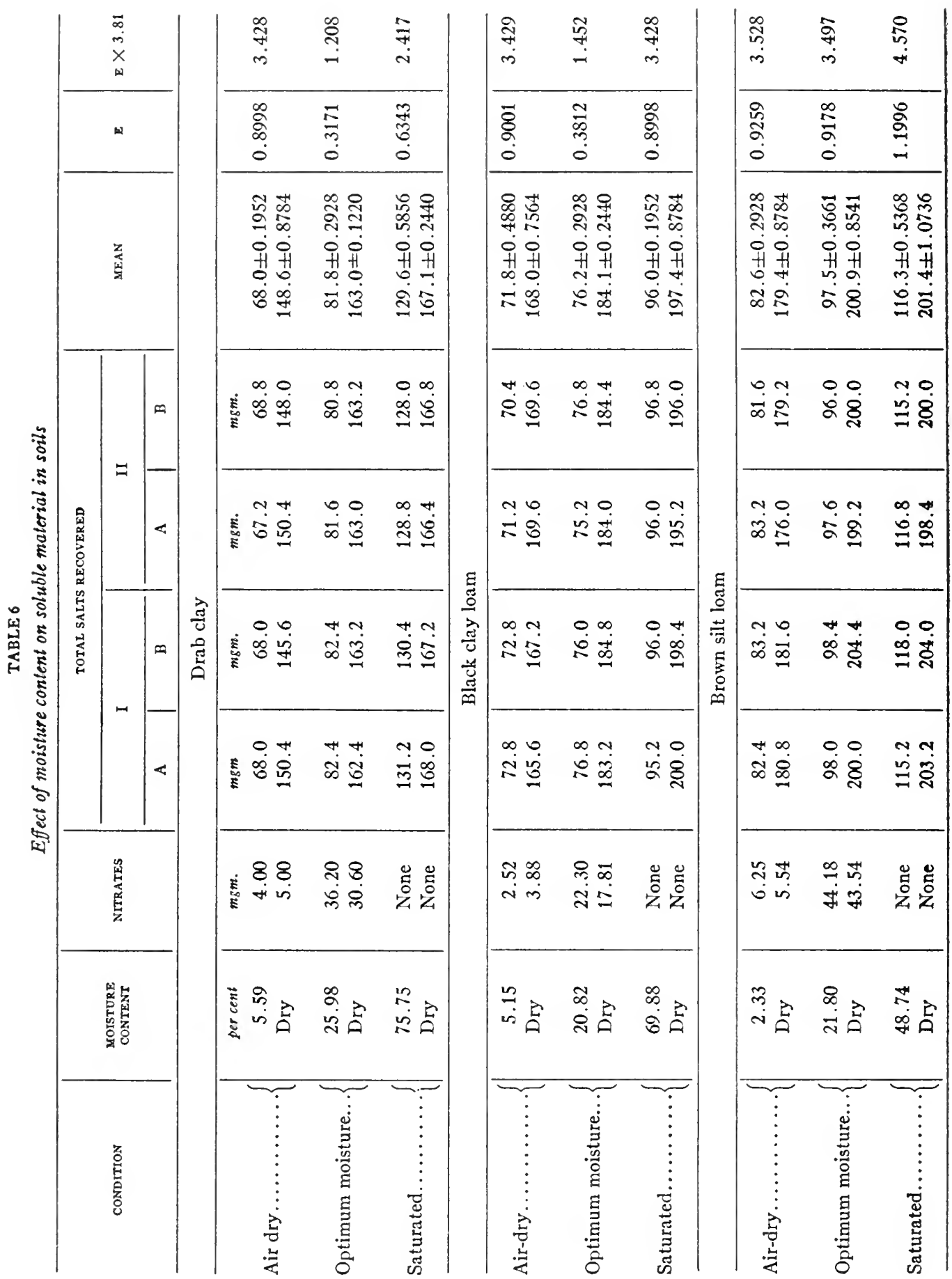




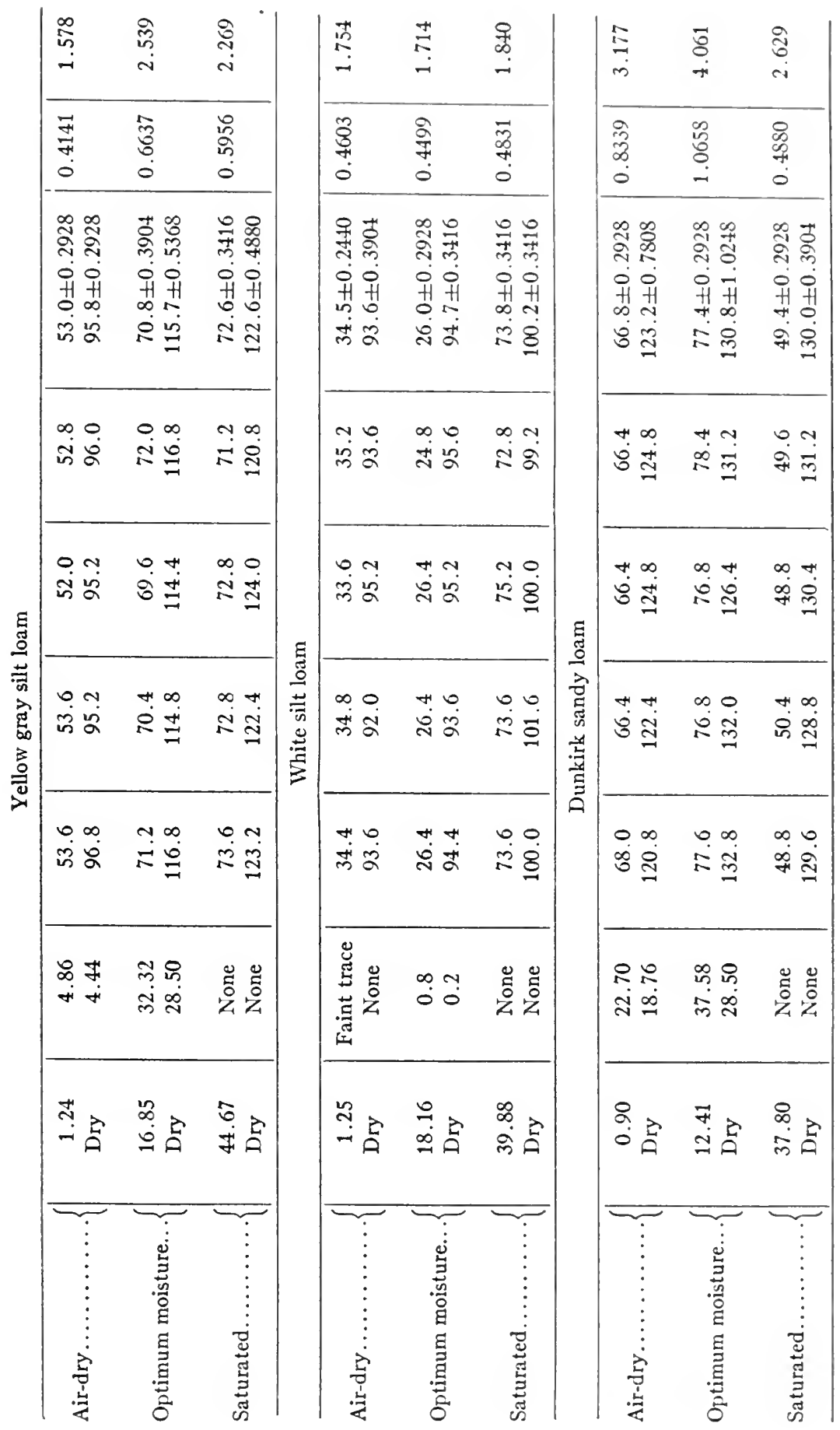


to prevent evaporation and the bottles with soil weighed at once after wiping them perfectly dry. After weighing, the soil was dried in the bottles at $105^{\circ} \mathrm{C}$. for 8 hours and again weighed. The loss is the hygroscopic moisture or, expressed as per cent on the basis of oven-dry soil, the hygroscopic coefficient.

The results of the determinations appear in table 7 .

As pointed out by Beaumont (3, page 492-493), the probable error of determinations of hygroscopic coefficient is high. The accuracy of this statement is well borne out by the figures in table 7 . His results indicated that slight variations in temperature made little difference in adsorption of water vapor so the only effort in this work was to keep the temperature sufficiently constant to prevent condensation of free water on the particles, or in the inter-

TABLE 7

IIygroscopic coefficients of air-dry soils used in experiment 4

\begin{tabular}{|c|c|c|c|c|c|c|c|c|c|}
\hline \multirow{3}{*}{ soIL } & \multicolumn{4}{|c|}{ WATER ABSORBED IN 7 DAYS } & \multirow{3}{*}{ MEAN } & \multirow{3}{*}{ 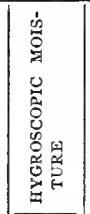 } & \multirow{3}{*}{ 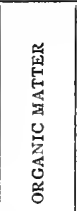 } & \multirow{3}{*}{ 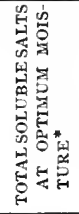 } & \multirow{3}{*}{ 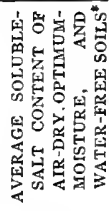 } \\
\hline & \multicolumn{2}{|c|}{ First trial } & \multicolumn{2}{|c|}{ Second trial } & & & & & \\
\hline & A & B & A & B & & & & & \\
\hline & & & & & & $\left|\begin{array}{c}\text { per } \\
\text { cent of } \\
\text { dry soil }\end{array}\right|$ & $\begin{array}{c}\text { per } \\
\text { cent }\end{array}$ & $m g m$ & $m g m$. \\
\hline 1. Drab clay.. & 11.66 & 11.62 & 11.30 & 11.62 & $11.550 \pm 0.061$ & 5.59 & 3.57 & 81.8 & 115.4 \\
\hline $\begin{array}{r}\therefore \text { Black clay } \\
\text { loam....... }\end{array}$ & 9.95 & 10.24 & 9.94 & 10.02 & $10.037 \pm 0.493$ & 5.15 & 5.50 & 76.2 & 125.0 \\
\hline $\begin{array}{r}\text { 3. Brown } \\
\text { loam...... }\end{array}$ & 4.45 & 4.62 & 4.41 & 4.47 & $4.487 \pm 0.0322$ & 2.33 & 4.80 & 97.5 & 140.1 \\
\hline $\begin{array}{l}\text { 4. Yellow gray } \\
\text { silt loam.. }\end{array}$ & 2.05 & 2.50 & 2.30 & 2.26 & $2.277 \pm 0.0598$ & 1.24 & 2.90 & 70.8 & 83.8 \\
\hline $\begin{array}{r}\text { 5. White silt } \\
\text { loam..... }\end{array}$ & 1.55 & 1.95 & 1.85 & 1.83 & $1.795 \pm 0.0299$ & 1.25 & 0.75 & 26.0 & 62.2 \\
\hline $\begin{array}{r}\text { 6. Dunkirk fine } \\
\text { sandy loam }\end{array}$ & 1.95 & 2.44 & 2.22 & 2.48 & $2.272 \pm 0.0915$ & 0.90 & 3.20 & 77.4 & 99.5 \\
\hline
\end{tabular}

* Data taken from table 6 .

stices of the soil. This latter seems to have occurred during the early part of this work as the hygroscopic coefficient was high and quite erratic. These figures seem to bear out Beaumont's conclusion, also, that other factors than total surface affect the adsorption of water. Soils 4 and 5 are very similar in texture, consequently in total surface, and the hygroscopic moisture actually in the soils, air-dry, is the same, yet when exposed to the same saturated atmosphere, soil 4 , with higher organic-matter and soluble-salt content, adsorbs 0.482 per cent more actual moisture, 27 per cent excess over soil 5 , the one of lower salt- and organic-content. In this comnection, let us compare soils 5 and 6 , in table 7 . White silt loam has much more surface than Dunkirk fine sandy loam. ${ }^{7}$ In the air-dry state they appear in their right order as

${ }^{7}$ No mecluanical analysis a vailable. 
regards hygroscopic moisture and surface having, respectively, 1.25 and 0.90 per cent hygroscopic moisture. However, when exposed to a saturated atmosphere for 7 days, they stand in a different relationship to each other, their positions being reversed, and instead of the soil with greater surface absorbing more moisture, more is taken up by the soil which has less surface, but contains more soluble salts. This tends to show that within certain limits, at least, soluble salts are of sufficient importance to reverse the normal effect of total surface exposed by a soil.

Considering table 7 in a broad, general way, the hygroscopic moisture content in the air-dry soil bears a normal relationship to the total surface, and when we consider surface and organic-matter content this same general relationship holds for hygroscopic coefficient except in case of the sandy loam where the discrepancy is due to its large quantity of soluble salts. The difficulty here lies in that we have not a single variable factor, but several, viz., size of particles, total surface, organic matter, and soluble salts.

Since it is almost, if not wholly impossible to control all factors at once, it may be necessary to work with synthetic soils, varying but a single factor at a time. These determinations of hygroscopic coefficients cannot yield much valuable evidence, except that, in a general way, the soils with the highest percentage of clay and colloids have the highest hygroscopic coefficients and within the limits of this experiment have the highest soluble salt content. However, the data are so meagre that no definite safe conclusion may be drawn.

\section{Experiment 6. Retention of nitrate by quartz and white silt loam}

The purpose of this experiment was to study the question whether clean quartz sand holds potassium nitrate, and if so, to what extent. This salt was selected because the acid radical is not generally supposed to be adsorbed to an appreciable degree, and also because it was available as a chemically pure substance.

The material used was a clean ground quartz. It was first leached with a 10 per cent solution of hydrochloric acid to remove any possible soluble material, then washed free of the acid and air-dried. It was then sifted into four grades, as used by the United States Bureau of Soils:

\begin{tabular}{|c|c|}
\hline & $\begin{array}{c}\text { Diameler } \\
m m\end{array}$ \\
\hline Coarse sand. & $1.00-0.50$ \\
\hline Mediun & $0.50-0.25$ \\
\hline Fine $s$ & $0.25-0.10$ \\
\hline Very fi & $0.10-0.05$ \\
\hline
\end{tabular}

White silt loam from experiments 4 and 5 was used also, since in the air-dry condition it was essentially deroid of nitrates.

The water-holding capacity of $50 \mathrm{gm}$. of each of these materials was then determined experimentally. Water was added from a burette and the materials were found to hold, without any loss by percolation on standing, the 
following quantities: coarse sand, $10 \mathrm{cc}$; medium sand, $10 \mathrm{cc}$; fine sand, $15 \mathrm{cc}$.; very fine sand, $17 \mathrm{cc}$; white silt loam, $18 \mathrm{cc}$.

According to Mosier and Gustafson (68) the surface per gram of the different grades, assuming perfect spheres of average diameter for the grades, is as follows: coarse sand, $30.2 \mathrm{sq}$. cm.; medium sand, $60.4 \mathrm{sq} . \mathrm{cm}$; fine sand, 129.3 sq. cm.; very fine sand, 302.1 sq. cm.; white silt loam, 2270.7 sq. cm. Analysis $^{8}$ of this latter soil shows (Bureau of Soils sizes) 1.5 per cent medium sand and coarser grades, 1.7 per cent fine sand, 7.5 per cent very fine sand, 70.6 per cent silt, and 18.3 per cent clay. The calculation of the surface per gram of white silt loam was based upon these percentages, the surface areas given above, and the assumption that $824.8 \mathrm{sq} . \mathrm{cm}$. is the surface of $1 \mathrm{gm}$. of silt and that $9090.2 \mathrm{sq} . \mathrm{cm}$. is the surface of $1 \mathrm{gm}$. of clay.

The figures for total surface per gram are undoubtedly more nearly accurate for white silt loam than for the quartz since the latter is angular and of all conceivable shapes with no spheres. The surface of the quartz must be considerably greater than the figures show, whereas in the white silt loam soil the angles have been worn off the particles to some extent, bringing them somewhat toward the spherical shape-yet the figures at best are but an approximation which may be of some value for purposes of discussion.

Solutions of potassium nitrate were then made up of such strength that $1 \mathrm{cc}$. of the first solution contained $0.1 \mathrm{mgm}$. of nitrate and the other, 0.5 mgm. of nitrate. The hygroscopic capacity of quartz is so low that this factor was ignored. A quantity of potassium nitrate solution equal to the waterholding capacity was added from an accurate burette to each of four 50 -gm. samples of the grades of quartz and of white silt loam. These moistened samples were covered to prevent evaporation and set aside over night to permit of any reaction or adjustment in the moist mass, after which two samples of each were placed in the oven at $105^{\circ} \mathrm{C}$. for 8 hours. Nitrates were determined immediately on the other two samples. Each was placed in a 500-cc. beaker and distilled water added to make a total of $250 \mathrm{cc}$; f for example, to the coarse sand containing $10 \mathrm{cc}$. of $\mathrm{KNO}_{3}$ solution, $240 \mathrm{cc}$. of distilled water was added and to the very fine sand having $17 \mathrm{cc}$. of the solution, $233 \mathrm{cc}$. of water was added. Thus the relationship throughout was 1 part of soil or quartz to 5 of water.

This experiment was run in two parts, $6 \mathrm{a}$ and $6 \mathrm{~b}$. In the first part, the nitrate solution used contained 100 parts per million, or $0.1 \mathrm{mgm}$. per cubic centimeter of nitrate and in the second, the solution contained 500 parts per million or $0.5 \mathrm{mgm}$. per cubic centimeter. In all other respects the two trials were identical. The stronger solution was used in the second trial because a dilution of $10 \mathrm{cc}$. of the first solution to $250 \mathrm{cc}$. was considered too great for securing results of the degree of accuracy desired.

The results of the first set of determinations are given in table 8 .

The results of the second set of determinations are given in table 9.

${ }^{8}$ This analysis was kindly furnished by Dr. Bizzell and Dr. Buckman. 
TABLE 8

Nitrate recovered from ground quarlz and while sill loam

(Nitrate solution, 100 p.p.m.or $0.1 \mathrm{mgm}$. per cc.)

\begin{tabular}{|c|c|c|c|c|c|c|c|c|c|}
\hline \multirow{2}{*}{ SIZE OF MATERIAL, } & \multirow{2}{*}{ CONDITION } & \multirow{2}{*}{$\begin{array}{l}\text { AMOUNT } \\
\text { NITRATE } \\
\text { ADEED }\end{array}$} & \multicolumn{2}{|c|}{$\begin{array}{c}\text { FIRST } \\
\text { EXTRACTION }\end{array}$} & \multicolumn{2}{|c|}{$\begin{array}{c}\text { SECOND } \\
\text { EXTRACTION }\end{array}$} & \multicolumn{2}{|c|}{$\begin{array}{c}\text { THIRD } \\
\text { EXTRACTION }\end{array}$} & \multirow{2}{*}{$\begin{array}{l}\text { RECOV- } \\
\text { FRED AY } \\
\text { FIRST } \\
\text { EXTRAC- } \\
\text { TION }\end{array}$} \\
\hline & & & $\begin{array}{l}\mathrm{NO}_{3} \\
\text { found }\end{array}$ & $\begin{array}{l}\mathrm{NO}_{3} \text { in } \\
250 \mathrm{cc} .\end{array}$ & $\begin{array}{l}\mathrm{NO}_{3} \\
\text { found }\end{array}$ & $\begin{array}{l}\mathrm{NO}^{2} \text { in } \\
250 \mathrm{cc} .\end{array}$ & $\begin{array}{l}\mathrm{NO}_{3} \\
\text { found }\end{array}$ & $\begin{array}{l}\mathrm{NO}_{3} \text { in } \\
250 \mathrm{cc} .\end{array}$ & \\
\hline \multirow{3}{*}{ Coarse sand. } & & $m g m$. & $p \cdot p \cdot m \cdot *$ & $m g m .^{*}$ & p.p. $m \cdot^{*}$ & $m g m$. & p.p. m. & $\mathrm{mgm}$ & percent \\
\hline & Moist & 1.0 & 3.22 & 0.805 & 0.48 & 0.12 & 0.33 & 0.08 & 80.50 \\
\hline & Dry & 1.0 & 3.15 & 0.79 & Trace & Trace & 0.36 & 0.09 & 79.00 \\
\hline \multirow{2}{*}{ Medium sand... } & Moist & 1.0 & 3.17 & 0.79 & 0.56 & 0.14 & 0.32 & 0.08 & 79.00 \\
\hline & Dry & 1.0 & 2.82 & 0.705 & Trace & Trace & 0.32 & 0.08 & 70.50 \\
\hline \multirow{2}{*}{ Fine sand. } & Moist & 1.5 & 4.67 & 1.17 & 1.03 & 0.26 & 0.42 & 0.10 & 78.00 \\
\hline & Dry & 1.5 & 4.11 & 1.03 & 0.62 & 0.15 & Trace & Trace & 68.67 \\
\hline \multirow{2}{*}{ Very fine sand.. } & Moist & 1.7 & 4.59 & 1.15 & 0.96 & 0.24 & Trace & Trace & 67.64 \\
\hline & Dry & 1.7 & 4.41 & 1.10 & 0.71 & 0.18 & 0.25 & 0.06 & 64.70 \\
\hline White silt loam. . & Moist & 1.8 & $5.57 \dagger$ & 1.393 & & & & & 77.40 \\
\hline
\end{tabular}

* Average of four determinations.

$\dagger$ Average of eight determinations.

TABLE 9

Nitrate recoicred from ground quarta

(Nitrale solution, 500 p. p. m. or $0.5 \mathrm{mgm}$. per cc.)

\begin{tabular}{|c|c|c|c|c|c|c|c|c|c|}
\hline \multirow{3}{*}{ SIZE OF MATERIAL } & \multirow{2}{*}{ CONDITION } & \multirow{2}{*}{$\begin{array}{c}\text { AMOUNT } \\
\text { OF } \\
\text { NITRATE } \\
\text { ADDED }\end{array}$} & \multicolumn{3}{|c|}{ PIRST EXTRACTION } & \multicolumn{3}{|c|}{ SECCND EXTRACTION } & \multirow{2}{*}{$\begin{array}{c}\text { TOTAL } \\
\text { NOO } \\
\text { RECOV. } \\
\text { ERED }\end{array}$} \\
\hline & & & \multirow{2}{*}{$\frac{\begin{array}{c}\text { Nos } \\
\text { found }\end{array}}{\text { p.p.m.* }}$} & \multicolumn{2}{|c|}{$\begin{array}{l}\mathrm{NO}_{3} \text { in } 250 \mathrm{cc} \text {. if } \\
\text { homogeneous }\end{array}$} & $\begin{array}{l}\mathrm{NO}_{3} \\
\text { found }\end{array}$ & \multicolumn{2}{|c|}{$\begin{array}{c}\mathrm{NO}_{3} \text { in } 250 \mathrm{cc} \text {. if } \\
\text { homogeneous }\end{array}$} & \\
\hline & & $m g m$. & & $m g m$. & percent & p.p.m.* & $m g m$ & percent & percest \\
\hline \multirow{2}{*}{ Coarse sand.. } & Moist & 5.0 & 17.74 & 4.435 & 88.7 & 1.21 & 0.302 & 6.0 & 94.7 \\
\hline & Dry & & 15.30 & 3.825 & 76.5 & 0.49 & 0.122 & 2.4 & 78.9 \\
\hline \multirow{2}{*}{ Medium sand... } & Moist & 5.0 & 15.45 & 3.886 & 77.5 & 1.103 & 0.276 & 5.5 & 83.0 \\
\hline & Dry & & 14.75 & 3.687 & 73.7 & 0.48 & 0.120 & 2.4 & 76.1 \\
\hline \multirow{2}{*}{ Fine sand..... } & Moist & 7.5 & 28.51 & 7.127 & 95.0 & 1.56 & 0.390 & 5.2 & 100.2 \\
\hline & Dry & & 27.27 & 6.817 & 91.0 & 0.48 & 0.120 & 1.6 & 92.6 \\
\hline \multirow{2}{*}{ Very fine sand.. } & Moist & 8.5 & 30.78 & 7.695 & 90.6 & 2.06 & 0.515 & 6.0 & 96.6 \\
\hline & Dry & & 29.26 & 7.315 & 86.0 & 0.703 & 0.176 & 2.3 & 88.3 \\
\hline
\end{tabular}

* Average of four determinations.

A glance at tables 8 and 9 shows that the recovery of nitrate was less complete with the more dilute solution, the average percentage of recovery being 76.3 for the moist quartz and 70.7 for the oven-dry quartz, compared 


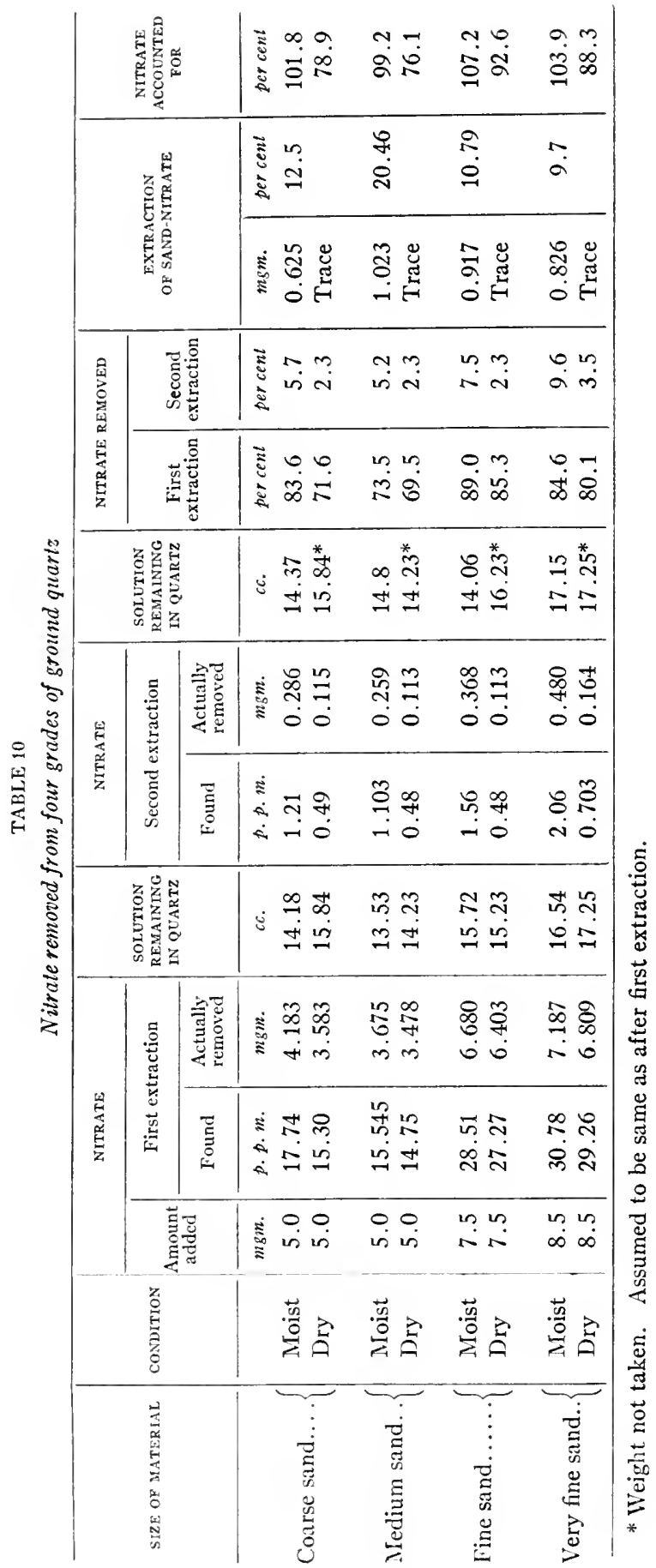


with 87.9 and 81.8 which are the corresponding figures for the more concentrated solution. Thus it is seen that the recovery from the oven-rlry quartz was less in both cases, less by 5.6 per cent for the dilute solution and by 6.1 per cent for the more concentrated solution. This relationship holds throughout the second extraction also. This seems to indicate a real loss of nitrate due to heating in the oven for 8 hours at $105^{\circ} \mathrm{C}$.

In order to test this point further, eight 10 -cc. samples of a nitrate solution containing 100 parts per million and eight 5-cc. portions containing 500 parts per million were treated with a few drops of saturated sodium carbonate solution and evaporated to dryness on the water-bath. The nitrates in isur samples of each were determined at once in the usual manncr. The remaining four samples of each concentration were dried in the oven at about $105^{\circ} \mathrm{C}$. for 8 and 21 hours, respectively. The results of all the determinations are given in table 11.

TABLE 11

Effect of heating at $105^{\circ} \mathrm{C}$. on quantity of nitrate recovered from quartz sand

\begin{tabular}{|c|c|c|c|c|}
\hline \multirow{3}{*}{ GRADE OF MATERLAL } & \multicolumn{4}{|c|}{ CONCENTRATION } \\
\hline & \multicolumn{2}{|c|}{$\begin{array}{l}\text { About } 0.1 \mathrm{mgm} \text { per } \\
\text { cubic centimeter }\end{array}$} & \multicolumn{2}{|c|}{$\begin{array}{l}\text { About } 0.5 \mathrm{mgm} \text {. per } \\
\text { cubic centimeter }\end{array}$} \\
\hline & Not heated & $\begin{array}{c}\text { After } \\
\text { heating }\end{array}$ & Not heated & $\begin{array}{c}\text { After } \\
\text { heating }\end{array}$ \\
\hline Coarse sand. & 40.125 & $43.75^{*}$ & 36.00 & 41.00 \\
\hline Medium sand. & 40.375 & $45.20^{*}$ & 37.25 & 41.00 \\
\hline Fine sand.... & 40.750 & $45.40^{*}$ & 37.00 & 40.25 \\
\hline Very fine sand . . . . . . . . . . . . & 40.000 & & 37.25 & 40.50 \\
\hline Average..... & 40.31 & 44.59 & 36.87 & 40.69 \\
\hline Percentage recovery . ...... & 100.00 & 90.39 & 100.00 & 90.86 \\
\hline
\end{tabular}

* Average of five readings, others average of four readings.

Since all of the above were compared with the same standard and all samples of each concentration were diluted to the same extent, the average colorimeter readings bear to each other exactly the same relationship as would the actual milligrams of nitrate, so the reading of unheated samples is considered 100 and the other found thus: $44.59: 40.31=100: \mathrm{x}$. Of the weaker solution, $10 \mathrm{cc}$. was diluted to $1000 \mathrm{cc}$. and of the stronger, $5 \mathrm{cc}$., to $2500 \mathrm{cc}$. in order to bring each to approximately 1 part per million for reading. From these figures the total milligrams of nitrate in each can be calculated. These figures show a loss of nearly 10 per cent of the nitrate after the period of heating at slightly above the boiling point. This is in accord with the earlier work recorded in this paper. For this reason further discussion here will deal with the unheated materials only.

In the case of the coarse and medium grades with the same quantity of nitrate added, the medium holds more, or gives up less, nitrate at both 
concentrations; the same relationship holds at both concentrations when we compare the nitrate recovered from the fine and very fine grades receiving, respectively, 15 and $17 \mathrm{cc}$. of nitrate solution. This tends to show that the difference is due to a surface effect.

Let us consider the very fine sand grade in tables 9 and 10 . There was incorporated in this grade $8.5 \mathrm{mgm}$. of nitrate. The first extraction removed $7.187 \mathrm{mgm}$. of nitrate in the $233.46 \mathrm{cc}$. of drainage (table 10). Had the entire $250 \mathrm{cc}$. of diluted nitrate solution been a homogeneous mixture, this quantity of solution could have contained only $7.695 \mathrm{mgm}$. of the original $8.5 \mathrm{mgm}$. incorporated.

In the second extraction of this grade, $0.48 \mathrm{mgm}$. of the $1.313 \mathrm{mgm}$. actually remaining in the quartz, was removed in the $232.85 \mathrm{cc}$. of drainage. Had this second solution been homogeneous, $0.515 \mathrm{mgm}$. of nitrate would have been recovercd, which still leaves $0.798^{9} \mathrm{mgm}$. of nitrate to be accounted for.

How shall we account for the apparent failure of $0.805 \mathrm{mgm}$. of nitrate to go into solution in the first, and $0.798 \mathrm{mgm}$. in second extraction? To the writer there seems but one answer to this question, that of King (46). When the nitrate solution came in contact with the quartz particles, a definite attraction due to the force of adhesion was set up. The quantity of the more concentrated solution added was greater than the sand could hold by adsorption, so that when the distilled water was supplied the nitrate solution held mechanically only, formed a homogeneous mixture with the water when stirred. The $16.54 \mathrm{cc}$. of solution remaining in the quartz after the first extraction, if of the same composition as the $233.46 \mathrm{cc}$. removed, would have contained $0.508 \mathrm{mgm}$. of nitrate. This is $0.028 \mathrm{mgm}$. in excess of the $0.48 \mathrm{mgm}$. actually removed in the second extraction, or, $0.007 \mathrm{mgm}$. less than would have been contained in the $250 \mathrm{cc}$. of solution had it been of the same composition as that draining from the sand.

Since the dilution is so much greater in the second extraction, it may be expected that the outer part of the film, less strongly adhering to the particles would tend to form a homogeneous mixture with the water, this together with the nitrate solution held mechanically only, and that coming by diffusion from the strongly held film, furnishes the whole of the nitrate removed in the second extraction. King's data, table A (p.177), shows that after six extractions the nitrate recovered is that coming from the strongly adhering film by diffusion.

Five months after the two extractions were made, the air-dry quartz samples which had stood in the laboratory in beakers covered with paper were themselves treated with phenoldisulfonic acid and nitrates determined in the usual way. The nitrate so determined is shown as milligrams and per cent of the total in the latter part of table 10. In no case did the samples which had been heated in the previous extractions show the presence of nitrates, while all

9 $8.5 \mathrm{mgm}$. total; actually removed by first extraction, $7.187 \mathrm{mgm}$., or $1.313 \mathrm{mgm}$. remained; $1.313-0.515=0.798 \mathrm{mgm}$. 
unheated samples contained considerable quantities of nitrates. No clain is made that the conditions under which these had been stored are such that the nitrate now recovered, together with that previously removed, should equal 100 per cent of the original quantity of nitrate used. However, it is notable that in all except the fine sand size the total recovery is nearly 100 ) per cent.

These data are not in accord with those of Noyes (71) who reports all nitrate recovered in one extraction nor with those of Bouyoucos (6), publisher since the above was written, who states that the soil solution is less concentrated at the immediate surface of the particles.

Under the conditions of this experiment, not all of the nitrate added to pure quartz nor to a soil containing but a faint trace of nitrate (white silt loam, table 6), was recovered in one extraction nor even in two extractions. While the data here reported are entirely too meager to warrant definite conclusions, yet it is significant that extracting the quartz itself brings the nitrate recovered so near 100 per cent of the total added.

This work corroborates in every important detail that of King (46) and though these data are meager they indicate clearly that with soils containing a moderately low percentage of capillary moisture, at, or slightly below optimum, much of the soluble salts are held in this film moisture. This film adheres so strongly to the particle that much of the soluble material it contains is given up to water on extraction by diffusion only and this explains, in part, the effect of airdrying. When the capillary moisture is lost the salts are left as minute crystals on the soil particles, and it is clear that quickly washing with water will bring these salts into solution so as to give a more homogeneous solution than can be obtained by washing a moderately moist soil in the same way.

When a soil is oven-dried we get all of the effect of air-drying just discussed, together with several additional effects. Heating at $105^{\circ} \mathrm{C}$. coagulates the colloids. This the oven-dry samples showed very clearly, on working them with a pestle in the mortar. With the heavier soils much difficulty was encountered in making a "thin paste," as the soil adhered so tightly to both the pestle and the mortar. After heating, there was no tenacity whatever, a heavy silt or clay loam working as easily as did fine sandy loam. This action on the colloidal matter would enable the water to come into more intimate contact with the material which exposes the major part of the total surface of the soil. As already shown, Hulett and Allen (37), the particles of colloidal size are more soluble than larger ones. This effect on colloids is undoubtedly' an important factor, and helps explain higher solubility in the soils with smallest particles.

Authors cited above hold that heating alters organic as well as inorganic materials in the soil, rendering them more soluble. While the physical factor in sands and silt loam has been shown to explain in part the increased recovery of salts due to heating, it scems to the writer that the effect on colloids and the well-known effect of heat in increasing the solubility of some minerals and organic matter also are important factors. 


\section{SUMMARX}

1. Oven-drying increased to a marked degree the quantity of water-soluble material removed from soil by 1:5 extraction with distilled water.

\% 2. Air-drying swamp soils increased the water-soluble material and ovendrying this air-dried soil brought about a still further increase.

3. Storing soils for 9 weeks at 8 to $12^{\circ} \mathrm{C}$. in open jars (in which water evaporated was restored each week) or in sealed tubes in its original condition did not markedly affect the total soluble material. Nitrification occurred in the open jars, while nitrates decreased, as a rule, in the sealed tubes.

4. Keeping soil at room temperature and optimum moisture content for 9 weeks did not materially affect the amount of soluble material, but there was a slight increase in all soils except white silt loam. Keeping these soils saturated at the same temperature, greatly increased the soluble material. In the first case nitrification was active while in the latter, denitrification was complete.

5. Oven-drying decreased the nitrate-content of these soils.

6. When potassium nitrate in two concentrations was added to four grades of quartz, it was not wholly recovered in one, or even two 1:5 extractions. From the more dilute solution 67 to 80 per cent of the nitrate were recovered in one extraction, while from the more concentrated, 77 to 95 per cent were recovered.

7. When potassium nitrate in a dish is heated in an oven at $105^{\circ} \mathrm{C}$. for 8 hours, after being evaporated to dryness, a distinct loss of nitrate occurs.

\section{GENERAL CONCLUSIONS}

The literature cited and the experimental work here reported both bring out one important point. They show the effect of drying at room temperature, and heating in an oven at slightly above the boiling point, and in the autoclave at various pressures and temperatures. In general, the quantity of soluble inorganic constituents and organic matter is increased, while temperatures above $100^{\circ} \mathrm{C}$. reduce the quantity of nitrates. These facts indicate that in planning soil biology studies, pot-culture or other greenhouse fertility investigations, the soils used should be kept under conditions strictly comparable as to aeration, moisture content and temperature in order to avoid the introduction of uncontrolled factors which might lead to erroneous conclusions.

\section{REFERENCES}

(1) Aitken, J. 1910 The fertilizing influence of sunlight. In Nature (London), v. 83, p. 37 .

(2) Allen, E. R., And Bonazzr, A. 1915 On nitrification. Ohio Agr. Exp. Sta. Tech. Bul. 7, p. 37 .

(3) Beaumont, A. B. 1919 Studies in the reversibility of the colloidal condition of soils. N. Y. (Cornell) Agr. Exp. Sta. Mem. 21, p. 479-524. 
(4) Bonsteel, J. A., Fippln, F. O. AND Carter, W. T. 1905 Soil survey of Tompkins County, N. Y. U. S. Dept. Agr., Field Operations Bur. Soils, 7th Rpt., p. 2\%.

(5) Bouxoucos, G. J. 1915 The freezing point methorl as a new means of measuring the concentration of the soil solution directly in the soil. Nich. Agr. Lixp. Sta. Tech. Bul. 24, p. 31-32.

(6) Bouyoucos, G. J. 1921 The concentration of the soil solution around the soil particles. In Soil Sci., v. 11, p. 131-138.

(7) Buck, E. 1915 Ráb: A unique system of cultivating rice in western India. In Internat. Inst. Agr. (Rome) Mo. Bul. Agr. Intel. and Plant 1)iseases, v. 6, p. 1111-1117. Abs. in Exp. Sta. Rec. (1916), v. 35, p. 138.

(8) Buddin, Walter 1914 Note on the increased nitrate content of soil subjected to temporary drying in the laboratory. In Jour. Agr. Sci., v. 6, p. 452-455.

(9) CARd, F. W., AND Blake, M. A. 1905 Report of the IIorticultural IDivision. In R. I. Agr. Exp. Sta. Ann. Rpt. 1905, p. 197-219.

(10) Christensen, H. R. 1917 Experiments in methods for determining reaction of soils. In Soil Sci., v. 4, p. 115-178.

(11) Coffey, G. N. and Party 1902 Soil Survey of St. Clair County, Ill. U.S. Dept. Agr., Field Operations Bur. Soils, 4th Rpt., p. 85.

(12) Coffey, G. N., Ely, C. W., Mann, C. J., et al. 1903 Soil Survey of McLean County, IIl. U. S. Dept. Agr., Field Operations Bur. Soils, 5th Rpt., p. 785.

(13) Coffey, G. N., Ely, C. W., et al. 1903 Soil Survey of Sangamon County, Ill. U. S. Dept. Agr., Field Operations Bur. Soils, 5th Rpt., p. 710-712.

(14) Coleman, D. A., Lint, H. C., And Kopeloff, N. 1916 Can soil be sterilized without radical alteration? In Soil Sci., v. 1, p. 259-274.

(15) Connor, S. D. 1916 Acid soils and the effect of acid phosphate and other fertilizers upon them. In Jour. Indus. Engin. Chem., v. 8, p. 35-40.

(16) Darbishire, F. V., And Russell, E. J. 1907 Oxidation in soils and its relation to productiveness. In Jour. Agr. Sci., v. 2, p. 305-326.

(17) Davy, Sir Humphrey 1813 Elements of Agricultural Chemistry. London. p. 299.

(18) Demerain, P. P., and Desioussy, M. E. 1896 Sur l'oxydation de la matiére organic du sol. In Ann. Agron., v. 22, p. 305-337.

(19) Dretrich, TH. 1901 Versuche über den Einfluss der Bodensterilisation auf das Wachstum der in dem sterilisierten Boden kultivierten Pflanzen. In Jahresb. Landw. Vers. Marburg, 1901-2, p. 16. Abs. in Centbl. Agr. Chem. (1903), p. 68 and in Jour. Agr. Sci. v, 2, p. 312.

(20) Dyer, B. 1910 Fertilizing effect of soil sterilization. In Nature (London), v. 83, p. 96.

(21) Ehrenberg, Paul 1915 Die Bodenkolloide, p. 40-201. Koehler and Volckmer, Leipzig.

(22) Fischer, Hugo 1912 Vom Trochnen des Bodens. In Centbl. Bakt. (ctc.), Abt. 2 , v. 36, p. $346-349$.

(23) Fletcher, P. 1910 The fertilizing influence of sunlight. In Nature (London), v. 83, p. $156-157$.

(24) FrANk, B. 1888 Ueber den Einfluss, welchem des Steriliziren des Erdbodens auf die Pflanzen-entwickelung ausübt. In Ber. Deut. Bot. Gesell. (General versamlungs Heft), v. 6, p. 87-97.

(25) Gedrortz, K. K. 1909 Influence of sterilization of the soil on the growth of plants on the soil. In Trudui Selsk. Khoz. Khim. Lab. St. Petersb., v. 6, p. 30-6-342. Abs. in Exp. Sta. Rec., v. 23, p. 221.

(26) Hald, A. D. 1910 The fertility of the soil. In Science, n. s.. v. 32, p. 36,3-371.

(27) Hald, Thomas Dennison $1915 \Lambda$ study in wetting and drying the soil. Unpublishied thesis, Cornell University, p. 1-30. 
(28) Hartwell, B. L., and Peuber, F. R. 1918 The presence of aluminum as a reason for the difference in the effect of so-called acid soil on barley and rye. In Soil Sci., v. 6, p. 259-280.

(29) Hasenbäusier, J., Coppenrath, E., and König, J. 1905 Einige neue Eigenschaften des Ackerbodens. In Landw. Vers. Stat., v. 63, p. 471-478.

(30) Hirgard, E. W. 1906 Soils, p. 321-331. MacMillan, New York.

(31) Hinson, W. M., and Jenisins, E. H. 1910 The management of tobacco seed beds. Conn. Agr. Exp. Sta. Bul. 166.

(32) Hopkins, C. G., Mosier, J. G., Pettit, J. H., and Fischer, O. S. 1913 Bond County soils. Ill. Agr. Exp. Sta. Soil Rpt. 8, p. 41-42.

(33) Hopkins, C. G., Mosier, J. G., Pettit, J. H., And Readhimer, J. E. 1912 Sangamon County soils. Ill. Agr. Exp. Sta. Soil Rpt. 4, p. 21 and 23-34.

(34) Hopkins, C. G., Mosier, J. G., Van Alstine, E., and Garrett, F. W. 1913 Pike County soils. Ill. Agr. Exp. Sta. Soil. Rpt. 11, p. 33.

(35) Hopkins, C. G., Mosier, J. G., Van Alstine, E., and Garrett, F. W. 1918 Cham paign County soils. Ill. Agr. Exp. Sta. Soil Rpt. 18, p. 27.

(36) Howard, A., And Howard, G. L. C. 1909-10 The fertilizing influence of sunlight. In Nature (London), v. 82, p. 456-457.

(37) Hulett, G. A., And Allen, L. E. 1902 The solubility of gypsum. In Jour. Amer Chem. Soc. v. 24, p. 667-679.

(38) Johnson, James. 1916 Preliminary studies on heated soils. In Science, n. s., v. 43, p. 434-435.

(39) Jounson, JAmES 1919 The influence of heated soils on seed germination and plant growth. In Soil Sci., v. 7, p. 1-104.

(40) Kelifey, W. P., ANd McGeorge, W. 1913 The effect of heat on Hawaiian soils. Hawaii Agr. Exp. Sta. Bul. 30, p. 5-38.

(41) Kelley, W. P., and Thompson, A. R. 1915 The organic nitrogen of Hawaiian soils. II: Effects of heat on soil nitrogen. In Jour. Amer. Chem. Soc., v. 36, p. $434-438$.

(42) King, F. H. 1901 Development and distribution of nitrates and other soluble salts in cultivated soils. Wis. Agr. Exp. Sta. Bul. 85, p. 1-48.

(43) King, F. H. 1904 Promising methods for the investigation of problems of soil and plant physiology, and some lines of investigation to which they are adapted. In Proc. Soc. Prom. Agr. Sci. (1904), p. 171-190.

(44) King, F. H. 1904 Investigations in Soil Management. Influence of Soil Management upon the Water-Soluble Salts in Soils and the Yield of Crops, p. 1-168. F. H. King, Madison, Wis.

(45) KING, F. H. 1905 Investigations in soil management. U. S. Dept. Agr. Bur. Soils Bul. 26, p. 1-124.

(46) Krng, F. H. 1909 The suspension of solids in fluids and the nature of colloids and solutions. Sep. from Trans. Wis. Acad. Sci., Arts and Letters 16 (1908), pt. 1, p. 275-288. Als. in Exp. Sta. Rec., v. 21, p. 19.

(47) KInG, F. H. 1911 Farmers of Forty Centuries, p. 142-143. F. H. King, Madison, Wis.

(48) Kinc, F. H. 1914 Soil Management, p. 297-299. Orange Judd Co., New York.

(49) King, F. H., And JefrRey, J. A. 1899 The soluble salts of cultivated soils. Wis. Agr. Exp. Sta. 16th Ann. Rpt., p. 219-242.

(50) King, F. H., AND Whitson, A. R. 1900 Soluble salts in cultivated soils. Wis. Agr. Exp. Sta., 17 th Ann. Rpt., p. 204-226.

(51) King, I. 11., AND Winisson, A. R. 1901 Development and distribution of nitrates in cultivated field soils. Wis. Agr. Exp. Sta. 18th Ann. Rpt., p. 210-231.

(52) King, F. H.. nND Whitson, A. R. 1902 Development and distribution of nitrates in cultivated soils. Wis. Agr. Exp. Sta. Bul. 93, p. 1-39. 
(53) Klein, Millard, A. 1915 Studies in drying of soils. In Jour. Amer. Soc. Agron., v. 7 , p. $49-77$.

(54) Kocri, G. P. 1917 The effect of sterilization of soils by heat and antiseptics upon the concentration of the soil solution. In Soil Sci., v. 3, p. 525-530.

(55) Kocח, A., AND LükeN, G. 1907 Ueber die Veränderung eines leichten Sandbodens durch Sterilisation. In Jour. Landw., v. 55, p. 161-172.

(56) König, J., Hasenbäumer, J. And Glenk, K. 1913 Ueber dic Anwendung der Dialyse und die Bestimmung der Oxydationskraft für dic Beurteilung des Bodens. In Landw. Vers. Stat., v. 79-80, p. 491-534.

(57) Kopeloff, N., and Coleman, D. A. 1917 A review of investigations in soil protozoa and soil sterilization. In Soil Sci., v. 3, no. 3, p. 197-269.

(58) Krüger and Schnemewind W. 1899 Ursache und Bedeutung der Salzpeterzersetzung im Boden. In Landw. Jahrb., v. 28, p. 216-252.

(59) Leather, J. W. 1912 Records of drainage in India. Mem. Dept. Agr. India, v. 2 , p. $63-140$.

(60) Lrebscher, G. 1893 Deut. Landw. Presse, no. 94, p. 976. Abs. in Jour. Agr. Sci., v. 2, p. 311.

(61) Lyon, T. L., ANd Bizzell, J. A. 1909 Changes produced in soils by subjecting them to steam under pressure. Abs. in Jour. Soc. Chem. Indus., v. 28, p. 721.

(62) Lyon, T. L., And Bizzels, J. A. 1910 Effect of steam sterilization on the watersoluble matter in soil. N. Y. (Cornell) Agr. Exp. Sta. Bul. 275, p. 129-155.

(63) Lyon, T. L., AND Bizzell, J. A. 1913 Water-soluble matter in soils sterilized and reinoculated. N. Y. (Cornell) Agr. Exp. Sta. Bul. 326, p. 205-224.

(64) Mann, H. H. 1908 Report of the agricultural chemist. Ann. Rpt. Dept. Agr. Bombay, 1908-9, p. 50-54. Abs. in Exp. Sta. Rec., v. 23, p. 129.

(65) Marbut, C. F., Bennett, H. H., Laphay, J. E., and Lapham, M. H. 1913 Soils of the United States. U. S. Dept. Agr. Bur. Soils Bul. 96.

(66) McGeorge, W.T. 1915 The effect of partial sterilization on plant growth. Hawaii Agr. Exp. Sta. Ann. Rpt. 1915, p. 37-38.

(67) Melion, J. W. 1916 Higher Mathematics for Students of Chemistry, and Physics, p. 521-524 and 528. Longmans, New York.

(68) Mosier, J. G., ANd Gustafson, A. F. 1917 Soil Physics and Management, p. 178. Lippincott, Phila.

(69) Nagoaka, 1911 Tokio Col. of Agr. Bul. 4, p. 265. Ref. in Wis. Agr. Exp. Sta. Res. Bul. 19, p. 5.

(70) Noyes, H. A. 1919 The effect of heat on the lime requirement of soils. In Jour. Amer. Soc. Agron, v. 11, p. 70-71.

(71) Noyes, H. A. 1919 Accurate determination of soil nitrates by phenoldisulphonic method. In Jour. Indus. Engin. Chem., v. 11, p. 213-218.

(72) Peterson, P. P. 1911 Effect of heat and oxidation on the phosphorus of the soil. Wis. Agr. Exp. Sta. Res. Bul. 19, p. 1-16.

(73) Prieffer, Th., AND Franke, E. 1896 Beitrag zur Frage der Verwertung elementaren Stickstoffs durch den Senf. In Landw. Vers. Stat., v. 46, p. 117-151.

(74) Pickering, S. U. 1908 Studies on germination and plant growth. In Jour. Agr. Sci., v. 2, p. 411-434.

(75) Pickering, S. U. 1908 The action of heat and antiseptics on soils. In Jour. Agr. Sci., v. 3, p. 32-54.

(76) Pickerring, S. U. 1910 Studies of the changes occurring in heated soils. In Jour. Agr. Sci., v. 3, p. 258-276.

(77) Pickerrng, S. U. 1910 Plant growth in heated soils. Ir Jour. Agr. Sci., v. 3, p. 277-284.

(78) Potter, R.S., And SNyder, R.S. 1915 The determination of nitrates in soil. In Jour. Indus. Engin. Chem., v. 7, p. 863-864. 
(79) Potter, R. S., AND SNyder, R. S. 1916 Extraction of nitrates from soil. In Jour. Amer. Soc. Agron., v. 8, p. 54-55.

(80) Potter, R. S., And Snyder, R. S. 1918 The effect of heat on some nitrogenous constituents of soil. In Soil Sci., v. 5, p. 197-212.

(81) Rahn, Отто 1907 Bakteriologische untersuchungen über das Trochnen des Bodens. In Centbl. Bakt. (etc.), Abt. 2, v. 20, p. 38-61.

(82) Richter, L. 1896 Ueber die Veränderung welcher Boden durch das sterilizieren erleidet. In Landw. Vers. Stat., v. 47, p. 269-274.

(83) Ritter, G. A. 1912 Das Trochnen der Erden. In Centbl. Bakt. (etc.), Abt. 2, v. 33 , p. $116-143$.

(84) Robinson, R. H. 1920 Concerning the effect of heat on the reaction between limewater and acid soils. In Soil Sci., v. 9, p. 151-157.

(85) Russeld, E. J. 1910 The fertilizing effect of sunlight. In Nature (London), v. 83 , p. 6,249 and 490 .

(86) Russell, E. J., And Hutchinson, H. B. 1909 The effect of partial sterilization of the soil on the production of plant-food. In Jour. Agr. Sci., v. 3, p. 111-144.

(87) Russeli, E. J., And Petherbrmge, F. R. 1913 On the growth of plants in partially sterilized soils. In Jour. Agr. Sci., v. 5, p. 248-287.

(88) Schmoeger, M. 1893 Ueber den Phosphor im Moorboden. In Ber. Deut. Chem. Gesel., Jahrgang 26, v. 1, p. 386-394.

(89) Schreiner, Oswald, and Failyer, G. H. 1906 Colorimetric, turbidity and titration methods used in soil investigations. U. S. Dept. Agr. Bur. Soils Bul. 31, p. $39-41$.

(90) Schreiner, Oswald, and Lathrop, E. C. 1912 The chemistry of steam heated soils. U. S. Dept. Agr. Bur. Soils Bul. 89, p. 1-37. Also in Jour. Amer. Chem. Soc., v. 34, p. 1142-1259.

(91) Schulze, C. 1906 Einige Beobachtungen über die Einwirkung der Bodensterilisation auf die Entwickelung der Pflanzen. In Landw. Vers. Stat., v. 65, p. 137-147.

(92) Seaver, J. F., AND Clark, E. D. 1910 Changes brought about by heating of soils and relation to the growth of pyronema and other fungi. In Mycologia, v. 2, p. 109-124.

(93) Seaver, F. J., AND Clark, E. D. 1912 Biochemical studies on soils subjected to dry heat. In Biochem. Bul. v. 1, p. 413-427.

(94) Skalskij, S. 1912 Work of the chemical laboratory of the Ploti Experiment Station, 1912. In Godichnyi Otchet Ploti Selsk. Khoz. Opytn Stanstii, v. 18, p. 133-227. Abs. in Exp. Sta. Rec., v. 30, p. 216, 349-380.

(95) SkALSkI], S. 1916 Method of sterilizing and chloroforming soil used in studying chernozem. In Iuzh. Russ. Selsk. Khoz. Gaz., 1916, no. 1, p. 7-8; no. 2, p. 6-7; no. 5, p. 5-10. Abs. in Exp. Sta. Rec., v. 38, 17-18.

(96) Stewart, G. R. 1918 The effect of season and crop growth on soil extract. In Jour. Agr. Res., v. 12, p. 311-368.

(97) Stone, G. E., Lodge, O. A., ANd Smith, R. G. 1912 Influence of soil decoctions from sterilized and unsterilized soils upon bacterial growths. Mass. Agr. Exp. Sta. 24th Ann. Rpt., p. 126-134.

(98) Stone, G. E., And Monolian, N. F. 1906 Report of the Botanist. Mass. (Hatch) Agr. Exp. Sta. 18th Ann. Rpt., p. 125-134.

(99) Stone, G. E., and Smith, R. G. 1898 Nematode worms. Mass. (Hatch) Agr. Exp. Sta. Bul. 55, p. 1-67.

(100) TACKE, B. 1897 Die Arbeiten im Laboratorium der Station in Bremen und die Feld, und Wiesenversuche in den bremischen Mooren. In Centbl. Agr. Chem., v, 26, p. 366-382.

(101) Tacke, Br., and Immendorf, H. 1898 Untersuchungen über die Phosphorverbindungen des Moorbodens. In Landw. Jahrb., Suppl., v. 274, p. 303-348. 
(102) Warington, R, 1882 On the determination of nitric acicl in soils. In Jour. Chem. Soc. (London), Trans., v. 41, p. 351-360.

(103) Whitsey, M., and Cameron, F. K. 1903 The chemistry of the soil as related to crop production. U. S. Dept. Agr. Bur. Soils Bul. 22, p. 1-71.

(104) Whitson, A. R. 1903 Studies in the development and distribution of nitrates and total water-soluble salts in field soils. Wis. Agr. Exp. Sta. 20th Ann. Rpt., p. 339-344.

(105) Wilsos, A. 1915 Changes in soil brought about by heating. In Sci. I'roc. Roy. Dublin Soc., v. 14 (n. s., no. 38), p. 513-520.

(106) Wilson, G. W. 1914 Studies of plant growth in heated soils. In Biochem. Bul., v, 3, p. 202-209. 


THIS BOOK IS DUE ON THE LAST DATE STAMPED BELOW

AN INITIAL FINE OF 25 CENTS WILL BE ASSESSED FOR FAILURE TO RETURN THIS BOOK ON THE DATE DUE. THE PENALTY WILL INCREASE TO $5 O$ CENTS ON THE FOURTH DAY AND TO \$1.00 ON THE SEVENTH DAY OVERDUE.

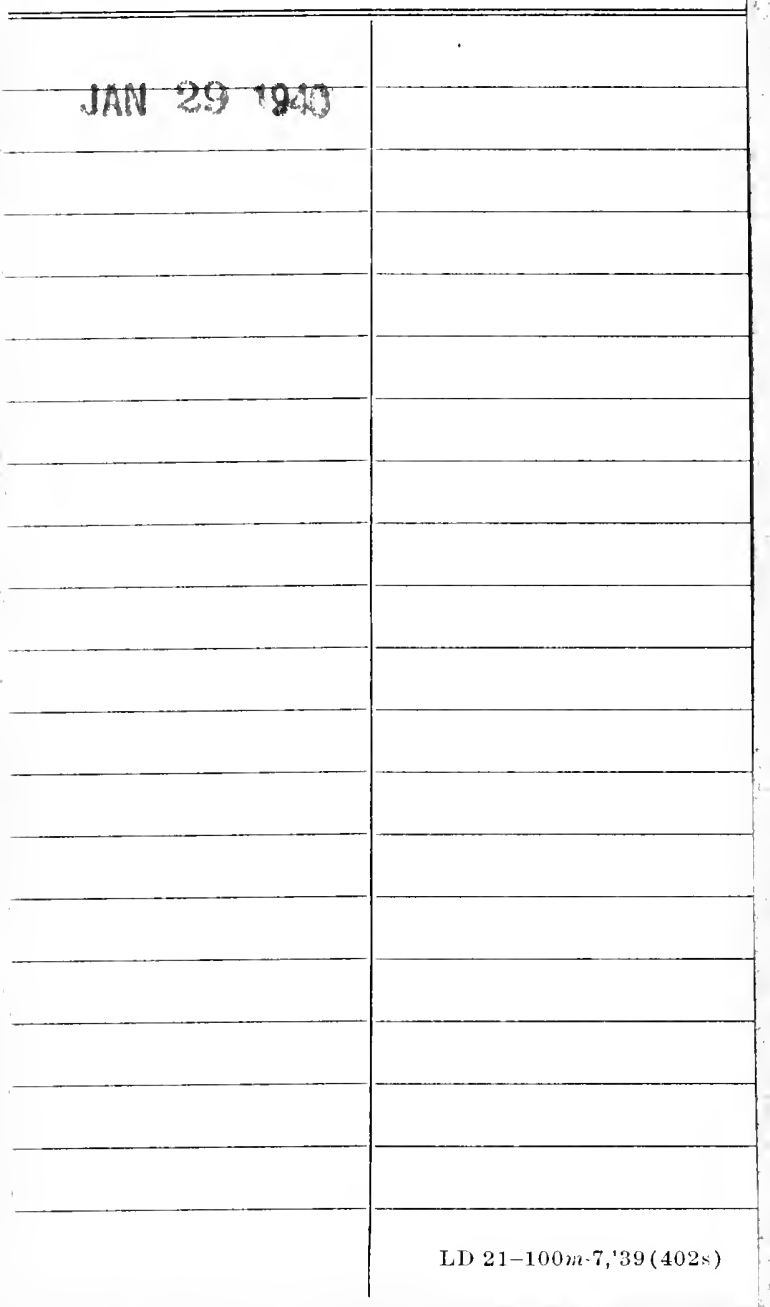


3
-1 3
$H$ 1
$H$

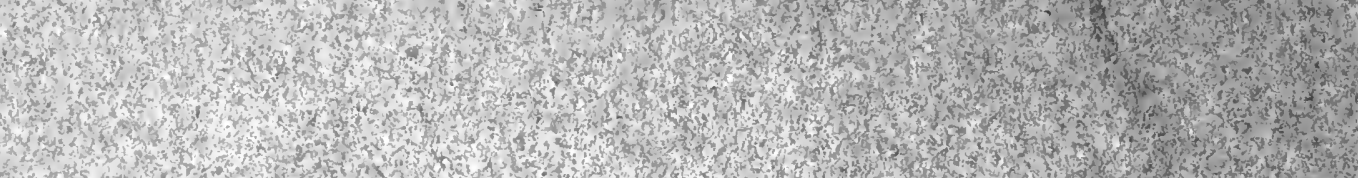

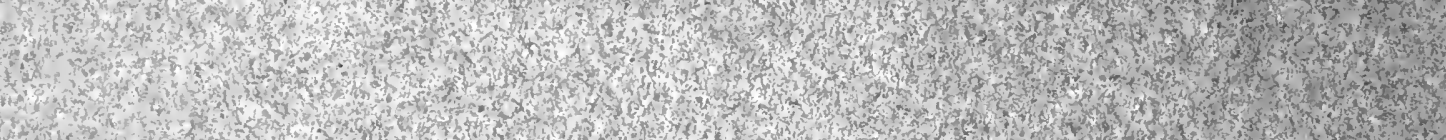

1
1 3
3 H. ind

Hint wis

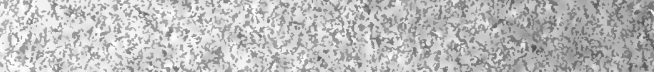
(n)

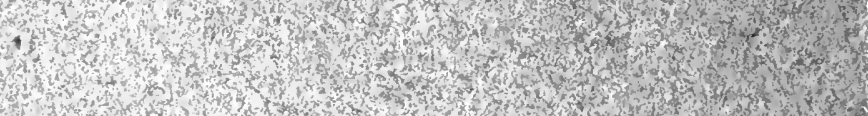

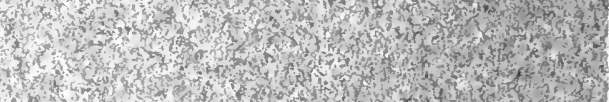
3.t.

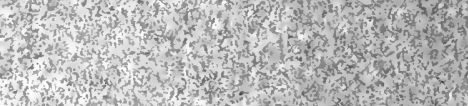

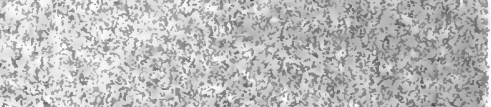

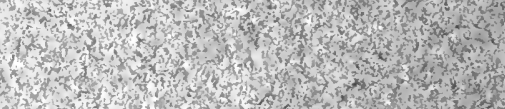
H.t. $*$
$H$

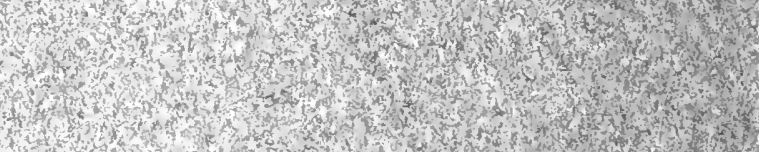
$62+x^{2}+x^{2}$

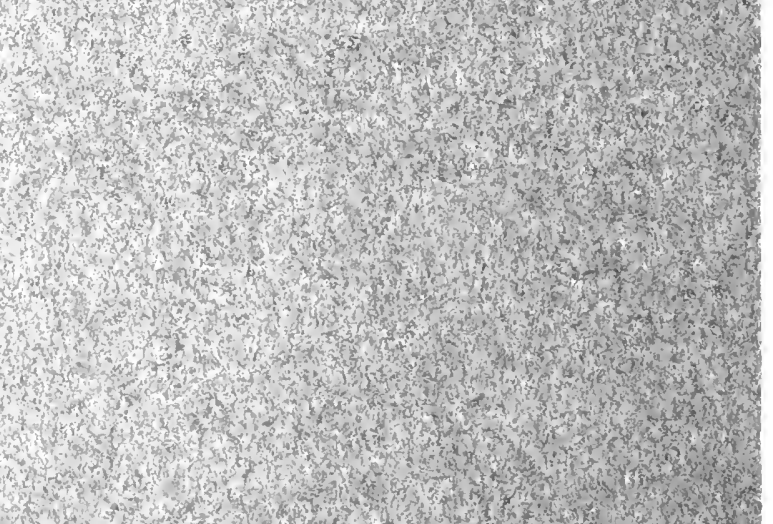

